\title{
Can springs cut canyons into rock?
}

\author{
Michael P. Lamb, ${ }^{1}$ Alan D. Howard, ${ }^{2}$ Joel Johnson, ${ }^{3}$ Kelin X. Whipple, ${ }^{3}$ \\ William E. Dietrich, ${ }^{1}$ and J. Taylor Perron ${ }^{1}$ \\ Received 13 December 2005; revised 27 February 2006; accepted 10 March 2006; published 25 July 2006.
}

[1] Amphitheater-headed valleys on Earth and Mars are often assumed to result from erosion by emerging spring water (i.e., seepage erosion or groundwater sapping) rather than by surface runoff. The origin of such valleys has implications for landscape evolution on Earth and the hydrologic cycle and associated potential for life on other planets. In this paper we explore the evidence for seepage erosion in bedrock to address whether valley morphology can be used as a diagnostic indicator of seepage erosion. Seepage erosion is an important process in loose sediment where hydraulic forces cause grain detachment, often resulting in amphitheater-headed valleys. However, the extension of these processes to resistant rock is uncertain. In sedimentary rocks, groundwater might control the shape and rate of valley formation. It is possible, however, that seepage plays only a secondary role to runoff processes. This seems likely in basaltic valleys on Earth, where little evidence exists for seepage erosion. Since the ability of seepage to erode bedrock valleys remains unclear and because many amphitheater-headed valleys were probably carved by other processes, seepage erosion should not be inferred based solely on valley form.

Citation: Lamb, M. P., A. D. Howard, J. Johnson, K. X. Whipple, W. E. Dietrich, and J. T. Perron (2006), Can springs cut canyons into rock?, J. Geophys. Res., 111, E07002, doi:10.1029/2005JE002663.

\section{Introduction}

[2] The common expression of river incision into irregular uplands is a network of roughly V-shaped valleys and intervening ridges, the amplitude of which diminishes toward the drainage divide. Deep amphitheater-headed valleys cut into relatively undissected uplands are strikingly different, and, where a full network develops, the form is distinctly stubby in appearance (Figure 1). Such channel networks would seem to require different processes than simply fluvial or debris flow incision. For over 100 years [e.g., Russel, 1902; Hinds, 1925; Wentworth, 1928; Higgins, 1984; Baker, 1990], it has been argued that the amphitheater shaped heads arise from the effects of groundwater exfiltrating along the base of a headwall, leading to mechanical and chemical breakdown and eventual collapse of the valley head front. Such channel networks are relatively uncommon, albeit spectacular where they occur, and had received little attention until early photographic images of Mars revealed numerous occurrences there [Sharp and Malin, 1975; Pieri, 1976; Carr and Clow, 1981]. Since then it has become generally accepted that the amphitheater shape is a reliable indicator of groundwater outflow driven erosion,

\footnotetext{
${ }^{1}$ Department of Earth and Planetary Science, University of California, Berkeley, California, USA.

${ }^{2}$ Department of Environmental Sciences, University of Virginia, Charlottesville, Virginia, USA.

${ }^{3}$ Department of Earth Atmospheric and Planetary Science, Massachusetts Institute of Technology, Cambridge, Massachusetts, USA.

Copyright 2006 by the American Geophysical Union. 0148-0227/06/2005JE002663\$09.00
}

with important consequences for interpreting the hydrologic cycle and potential for life on Mars [Baker, 1982; Tanaka, 1986; Squyres, 1989; Squyres and Kasting, 1994; Malin and Carr, 1999; Gulick, 2001; Aharonson et al., 2002; Jaumann and Reiss, 2002]. Inspired by Mars observations, studies have been conducted on what appear to be terrestrial analogs, especially in the American Southwest [Laity, 1983; Laity and Malin, 1985; Howard and Kochel, 1988] and Hawaii [Kochel and Piper, 1986; Kochel and Baker, 1990]. It has become commonplace in terrestrial studies to assume spring-driven erosion processes ("seepage erosion" in the sense of Dunne [1990]) based largely on valley topographic form [Mars Channel Working Group, 1983; Higgins, 1984; Baker, 1990; Uchupi and Oldale, 1994; Hoke et al., 2004].

[3] Caution has been proposed regarding this morphometry-based inference. Howard [1988] and Howard and Kochel [1988] review terrestrial field studies and Mars observations and conclude that morphometric features may not be uniquely associated with seepage erosion. They emphasize that, due to bedrock strength (which demands seepage weathering precede seepage erosion) and the large size of amphitheater-shaped canyons on Mars, enormous discharges of water (requiring repeated recharge of upslope drainage areas) would be necessary to create these canyons by seepage erosion (if it in fact occurs). Here we further question the reliability of morphometric features as indicators of seepage erosion. We develop this proposal by first reviewing where seepage erosion unambiguously leads to amphitheater shaped valley heads: in loose sediment. We then summarize numerous studies that have proposed seep- 

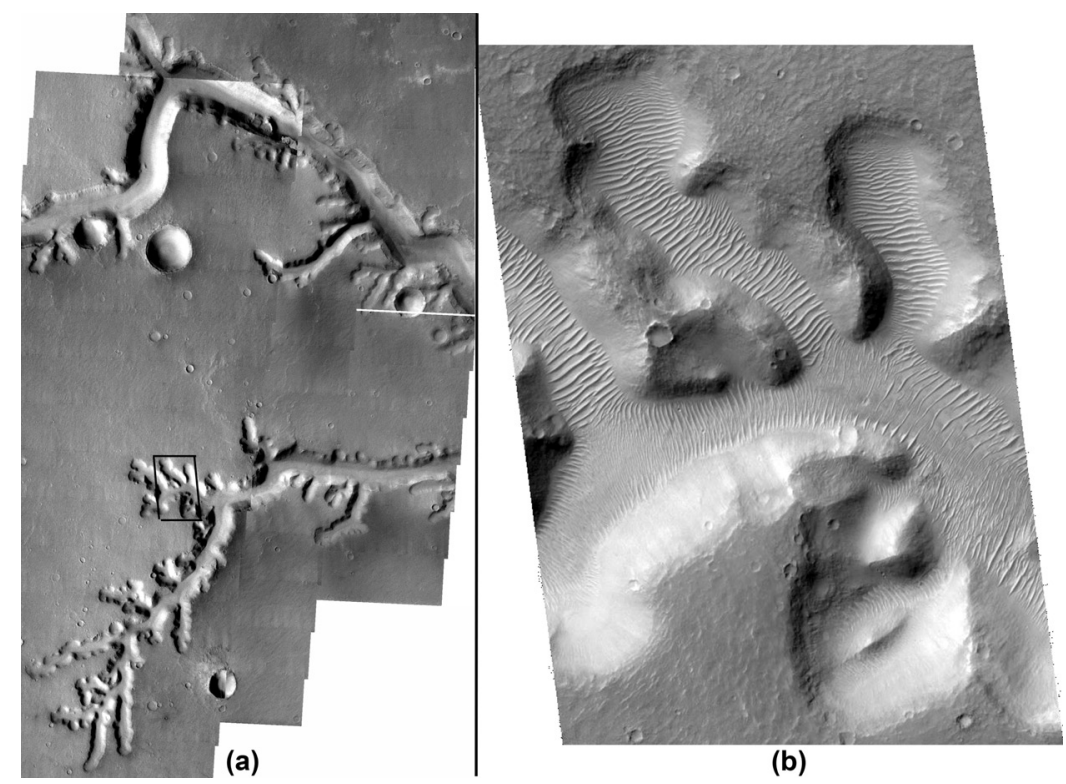

(b)

Figure 1. Nirgal Valles on Mars. (a) Nirgal Valles main channel (top) and stubby, branching tributaries (bottom). Mosaic of THEMIS VIS images V07929005, V01962005, and V1600005. Image width is about $27.6 \mathrm{~km}$. North is to top of image. Mosaic is centered at about $-27.2^{\circ} \mathrm{S}$ and $317.0^{\circ} \mathrm{E}$. (b) Detail of tributary headwalls from MOC NA image E02-02651, image width $2.89 \mathrm{~km}$. Location of image is shown by box in Figure 1a. Ridges along channel floor are eolian megaripples. Eolian infilling, mass wasting and impact cratering have infilled the valley floors and reduced the steepness of the valley walls, so that no definitive inferences can be made about the processes forming the valley network.

age erosion in bedrock, emphasizing ones since 1988, and conclude that the evidence is most often ambiguous. This leads to a reanalysis of the two most cited terrestrial analog sites: the Colorado Plateau and Hawaii. While some seepage weathering due to salt precipitation clearly takes place in the Colorado Plateau, spring flow is not able to remove boulders and gravel that tumble onto the canyon floor. Moreover, high-magnitude flash floods capable of transporting boulders and incising into coherent rock are a common occurrence in this landscape and must have contributed significantly to the long-term evolution of these canyons. In Hawaiian basalts, we have found no direct evidence of seepage erosion. Instead, waterfalls appear to dominate erosion at the valley heads and runoff is necessary to transport collapsed material. Finally, we review the evidence for seepage erosion on Mars. We conclude that unreliability of morphologic criteria, coupled with the lack of local evidence of erosion processes (e.g., alcoves, seepage faces, boulder beds) due to post canyon formation modifications by mass wasting, eolian deposition and impact effects, makes the case for seepage on Mars equivocal.

\section{Seepage Erosion Definitions}

[4] In this paper we follow the terminology proposed by Dunne [1990]. Seepage is groundwater that emerges from rock or sediment. Weathering processes that are facilitated by seepage (e.g., salt precipitation, chemical dissolution or frost growth) are collectively referred to as seepage weathering. The removal of mass from a seepage face is termed seepage erosion. In unconsolidated sediments, seepage erosion can occur in the absence of seepage weathering if the discharge of seepage water is sufficient to detach and mobilize the sediment. However, in rock, seepage weathering is needed to render the rock cohesionless before seepage erosion can occur. Sapping describes processes that undercut or undermine a scarp leading to an overhang. A variety of processes cause sapping (e.g., cut bank erosion by a meandering river, wave erosion of a sea cliff, seepage erosion at the base of a scarp or headwall, plunge pool erosion at the base of a waterfall). The term groundwater sapping then refers to sapping induced by seepage erosion.

\section{Seepage Erosion in Sediment}

[5] By far the most conclusive studies connecting seepage erosion to valley morphology have been in sediments with little to no cohesion. Here we briefly summarize studies on seepage erosion in sediments to motivate our discussion of seepage erosion processes in rock. For earlier, more encompassing reviews of seepage erosion in sediments the reader is referred to Higgins [1984] and Dunne [1990]. Seepage can carve valleys in sand by undermining the seepage face and evacuating collapsed sediment [Kochel et al., 1985; Howard and McLane, 1988; Owoputi and Stolte, 2001; Schorghofer et al., 2004]. The eroding headwall lowers the local hydraulic head, focusing groundwater flow to the seepage face, which in turn accelerates erosion of the seepage face. This feedback, first envisioned by Dunne [1980], has been shown to produce valleys with amphitheater heads in sand boxes [Howard and McLane, 1988], sandy beaches [Higgins, 1982], and in numerical simulations [Howard, 1995]. The rate of headward erosion is primarily limited by the capacity of the seepage water to 
transport sediment from the seepage face, which scales with seepage discharge [Howard and McLane, 1988]. If a valley becomes choked with colluvium it will transmit the water through the colluvium (as groundwater) and thus shut off seepage erosion [Dunne, 1990].

[6] Larger amphitheater-headed valleys carved into loose sediments have also been attributed to seepage erosion. For example, headcut erosion in gullies or headwater hollows can be due to seepage erosion [Higgins et al., 1990; Dietrich and Dunne, 1993]. A relict seepage erosion origin has been postulated for the flat-floored amphitheater-headed valleys formed in glacial outwash sediments of Cape Cod and Martha's Vineyard and Nantucket Islands, Massachusetts [Uchupi and Oldale, 1994]. Similarly, large amphitheater-headed valleys cut into Quaternary shallow marine and terrestrial sands and gravels in South Taranaki, New Zealand, have been attributed to seepage erosion [Pillans, 1985]. In the Canterbury Plain, New Zealand, Schumm and Phillips [1986] described similar seepage erosion valleys carved into fluvial deposits from Pleistocene drainage of the Southern Alps. However, they concluded that the valleys were originally formed from runoff processes and were later widened by seepage erosion resulting in amphitheater-headed morphologies. They postulated that valley growth is limited by the competence of the flow to transport the coarser gravels that form a lag on the valley floor and that precipitation-induced runoff is probably necessary to remove these gravels.

[7] Schumm et al. [1995] proposed that valleys in the Florida panhandle in essentially unconsolidated sediments of the Pleistocene Citronelle formation were formed by seepage erosion. The valleys typically have vegetated angle-of-repose walls, symmetric amphitheater heads (locally known as "steepheads"), flat bottoms, short first-order streams, and springs emerging from sands and sandy clays at the bottom of the valley headwalls. Very high infiltration rates into the unconsolidated sediment and dense vegetation are consistent with a lack of channels upslope of the amphitheater heads. Amphitheater-headed valleys are found in nonmarine quartz sands with discontinuous layers of clay, indurated "hardpans", and gravel [Schumm et al., 1995], as well as unconsolidated beach sands [Lobkovsky et al., 2005], suggesting that lithologic strength or permeability contrasts are unimportant in setting the first-order morphology of these valleys.

[8] In sediments finer than sands, erosion at the seepage face is typically limited by detachment of the grains, rather than the ability of the water to transport sediment. In silts and clays the permeability is low such that the groundwater discharge is often less than that required to overcome the cohesive forces of the grains [Dunne, 1990] and channelized runoff, sometimes aided by moisture-induced disaggregation of the sediment, is the dominant erosive agent. Feedback processes in cohesive sediment often cause tunneling or piping [Jones, 1981; Higgins, 1984; Dunne, 1990].

\section{Seepage Erosion in Rock}

[9] Dunne [1980] proposed that seepage erosion processes similar to those observed in sediments could occur in rock. Before rock can be eroded by seepage, however, it must first be rendered cohesionless by seepage weathering [Dunne, 1980; Dietrich and Dunne, 1993]. Dunne [1980] envisioned seepage weathering occurring as emerging groundwater weakens the bedrock while increasing its porosity and hydraulic conductivity through chemical weathering. For example, in Vermont, Dunne [1980] described siliceous and calcareous granulite bedrock that was friable and stained brown where springs emerged along joints. Once weakened to the point of cohesionless sediment, the material can be removed through drag forces induced by the flowing seepage water in the manner described above for seepage erosion in sediment. Seepage erosion at the base of a headwall might then lead to undermining (i.e., sapping), collapse of the rock above, and retreat of the headwall. Similar to seepage in sediments, Dunne [1980] proposed that focusing of groundwater discharge at the channel head and seepage weathering form a positive feedback leading to the formation of channels through the retreat of the headwall. Thus channels could be initiated and extended, creating channel networks without the aid of surface runoff.

[10] Howard [1995] showed numerically that amphitheater-headed valleys can form from seepage erosion in rock if the erosion rate of the valley head scales with groundwater discharge. Such a relationship has been used in models of landscape evolution [Willgoose et al., 1991; Stark, 1994; Howard, 1995; Hovius et al., 1998]. However, potential seepage weathering mechanisms (e.g., chemical weathering, wetting and drying, freeze-thaw, salt wedging, root wedging, and ice needle growth [Higgins, 1984]), have yet to be investigated quantitatively. It is possible that for some of these mechanisms, weathering rate is inversely related to seepage discharge. For example, weathering due to salt precipitation facilitated by seepage evaporation [e.g., Laity, 1983] could be less effective if seepage discharge exceeds the evaporation rate [Mason and Pederson, 2004]. Freezethaw processes might be less effective for large springs with a greater thermal inertia. For these cases, the feedback between headwall retreat and seepage erosion, described above, could be negative. Focusing of groundwater flow toward the migrating headwall [Dunne, 1980] would then cause a decrease in seepage weathering and an eventual demise of the canyon.

[11] It is difficult to observe seepage erosion in bedrock because, if it occurs, it requires long timescales. Therefore valleys formed by seepage erosion are often identified based largely on their form [e.g., Baker, 1982; Mars Channel Working Group, 1983; Higgins, 1984; Kochel and Piper, 1986; Baker, 1990; Luo, 2000; Hoke et al., 2004]. These studies typically assume that seepage erosion valleys in rock have amphitheater heads, drawing on the studies of seepage erosion in sediments.

[12] Instead of a morphometric analysis, we focus here on mechanistic evidence for seepage erosion. In order for seepage to erode a bedrock canyon it must be able to (1) weather the seepage face and (2) transport collapsed material. Similarly, if a case is to be made for surface runoff, it must be able to do the same: erode bedrock and transport sediment. Physical erosion of bedrock by surface runoff can occur by a variety of mechanisms (e.g., abrasion, plucking and cavitation [Whipple, 2004]) and 


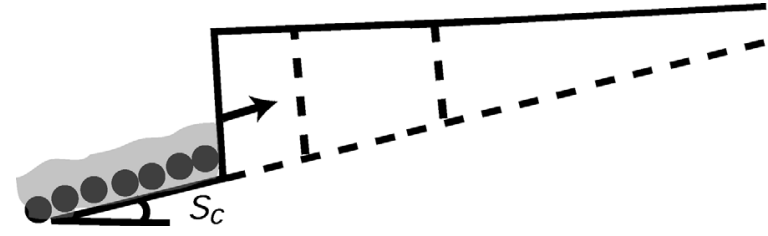

Figure 2. Schematic of upslope headwall propagation due to seepage erosion, illustrating the necessary condition of debris removal. If the discharge is not sufficient to transport collapsed debris at a given slope, the bed will aggrade until the slope surpasses the critical slope necessary for transport. If this critical slope $S_{c}$ is greater than the regional topographic slope, then the headwall will diminish in height as it propagates upslope, eventually leading to the demise of the canyon.

some process-based rate laws for quantifying geomorphic change due to these processes have been developed [e.g., Whipple et al., 2000; Sklar and Dietrich, 2004]. Unfortunately, seepage weathering and erosion in rock have not been quantified, nor have mechanistic rate laws been proposed. In fact, in most studies the mechanism by which seepage erosion occurs has not been identified. Thus deciphering the processes responsible for weathering or eroding a bedrock headwall is necessarily qualitative. For seepage weathering and erosion, we expect weathered and mechanically weakened rock, secondary porosity, and alcoves around the seepage face. For runoff processes, we expect scoured bedrock, plucked blocks and plunge pools. A spring does not necessarily indicate seepage erosion, just as a waterfall does not necessarily indicate plunge pool erosion. Many large springs exist that are not associated with amphitheater-headed valleys [e.g., Whiting and Stamn, 1995]. It should be noted that this qualitative description of erosion processes does not prove process dominance for valley formation. Rather, these observations provide the first step toward mechanistic hypotheses for amphitheater valley formation, which will then require further exploration through the development and testing of quantitative geomorphic rate laws [e.g., Dietrich et al., 2003].

[13] In addition to bedrock erosion and weathering, evacuation of collapsed material from the valley headwall also provides a necessary constraint for valley formation, which fortunately can be assessed quantitatively with sediment transport theory. The talus of collapsed rock from above the seepage face is not likely to be weathered by seepage, at least initially. If the talus cannot be removed, it will eliminate the exposed seepage face [Dunne, 1990] and buttress the headwall, preventing further retreat and leading to the demise of the canyon. As talus accumulates on the valley floor, it might reach a slope in which sediment transport can occur. However, if this slope is greater than the regional topographic slope updip of the retreating headwall, the headwall will decrease in height as it migrates upstream, again leading to the eventual demise of the canyon (Figure 2). Thus large discharges of water or steep regional slopes are required to maintain an upslope propagating headwall, or substantial time is required to weather the talus to transportable sizes.

\subsection{Case Studies}

[14] Mastronuzzi and Sanso [2002] examined valley networks developed in the permeable limestone and calcarenite in the Apulia region of southern Italy. These valleys are currently dry, but Mastronuzzi and Sanso reasoned that high water tables during sea level highstands might have promoted seepage erosion at the valley heads. They suggested that the low relief of the region caused a lack of overland flow and high infiltration rates. Besides the morphometric evidence, they mentioned notches, tafoni, and caves along the valley walls. These erosional forms likely indicate some seepage or groundwater erosion. Because of the calcareous substrate, erosion might have occurred by dissolution.

[15] In Yorkshire, England, a plateau consisting of lower Jurassic calcareous grit and upper Oxford Clay is cut by amphitheater-headed valleys [Nash, 1996]. The upper portion of the lower calcareous grit sandstone has more silica cementation and defines that plateau. The lower calcareous grit provides a permeable aquifer bounded roughly on the bottom by the upper Oxford Clay. Groundwater emerges along bedding planes in a $20-30 \mathrm{~cm}$ thick zone. Rock above the seepage zone shows little evidence for weathering while rock below the seepage zone shows substantial weathering with material broken down into centimeter-sized angular pieces. There is an increase in jointing and fracturing along the bedding planes in the seepage zone. Like the Apulia valleys, dissolution might be important, particularly because of the calcareous substrate. Alternatively, the calcareous grit is weakly consolidated and hydraulic forces might be sufficient to mobilize grains with little or no seepage weathering. Nash [1996] proposed that seepage erosion was responsible for headward development of the valleys. However, he stressed that there also has been significant contribution from surface runoff with channels evident upstream of the valley headwalls and that much of the drainage network was originally formed by surface flow from glacial meltwater.

[16] Some soil or sediment mantled bedrock valleys have been proposed to have a seepage origin. Here it is unclear if seepage erosion is occurring in the soil, bedrock, or both. For example, Onda [1994] reports on amphitheater-headed valleys in Obara, Japan where a thick soil covers granodiorite bedrock. Seepage erosion was observed in the soil. The deep amphitheater-heads of the valleys, however, suggest that the form of the valleys is expressed in the bedrock, not just in the soil cover. It is unclear how the erosional processes in the soils affect the bedrock. Onda [1994] proposed simultaneous seepage erosion in rock at the soil-rock interface through enhanced chemical weathering and in soil at the soil-air interface where visual observations of seepage erosion were made. Another possible explanation might be that in reducing the soil thickness, seepage erosion indirectly increased the erosion of bedrock at the valley head by increasing the rate of local soil production [e.g., Heimsath et al., 1997]. It also remains possible that the soil mantle is sufficiently thick, such that the valleys are not cut into the underlying bedrock. In this case, the amphitheater form is a result of seepage erosion in the soil only. For example, in his Vermont study site, Dunne [1980] 


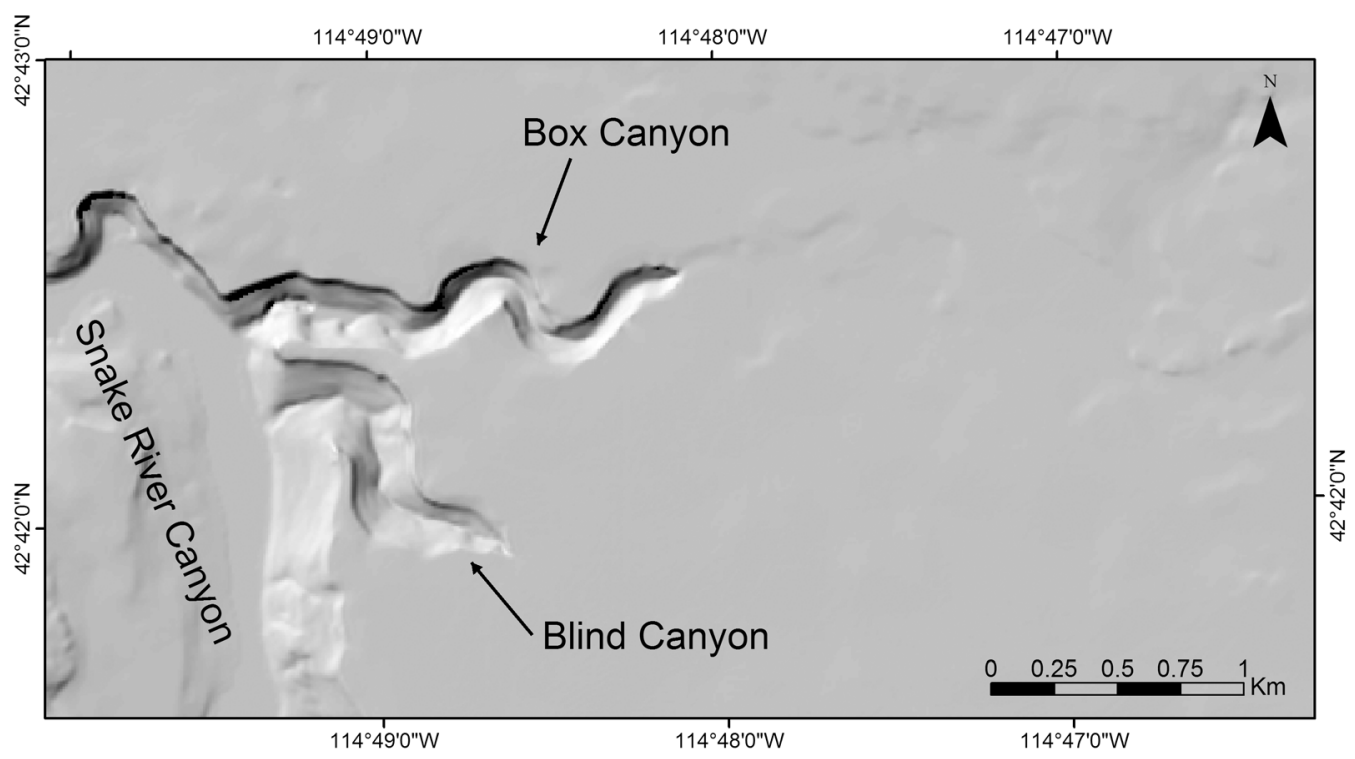

Figure 3. Shaded relief map of $10 \mathrm{~m}$ topographic data (USGS NED) of Box and Blind canyons, Idaho. Although the regional topographic slope dips toward the canyon, the landscape is largely undissected upslope of the canyons, which end in near vertical headwalls.

noted seepage erosion in the sediment, but did not document erosion of the underlying substrate.

[17] Two studies in areas underlain by basalt deserve mention here due to the potential of a similar lithology on Mars [Scott and Tanaka, 1986]. On the basis of overhangs near plunge pools, Pederson [2001] interpreted seepage erosion to be an important erosional process at Akaka and Rainbow Falls that spill over basaltic bedrock on the island of Hawaii. We observed in August 2004 that the alcoves near the base of these waterfalls seem to be associated, at least spatially, with waterfall plunge pools. Although the alcove at Rainbow Falls is almost cave-like and extends on the order of $10 \mathrm{~m}$ behind the waterfall, we found semicircular lines of twigs and debris deep within the alcove indicative of plunge pool spray. Macdonald et al. [1983] interpreted the alcove at Rainbow Falls to be the result of a weaker lava bed overlain by a more resistant waterfallforming bed. Bedrock scours and potholes upstream of Rainbow Falls indicate that surface flow can cause substantial erosion of the more resistant bedrock. Thus headwall retreat via plunge pool undercutting of the weaker bed seems plausible.

[18] Several large amphitheater-headed valleys exist as tributaries to the Snake River near Hagerman, Idaho. These valleys were first proposed to have a seepage erosion origin by Russel [1902] and later by Stearns [1936] because of their amphitheater heads and because some of the largest springs in North America emanate from their heads. In addition, there is no overland flow currently entering the canyons and there is little development of a drainage network upslope of the canyons (Figure 3). We have begun to study one of these canyons, Box Canyon, which has the 11th largest spring in the United States $\left(\sim 10 \mathrm{~m}^{3} / \mathrm{s}\right.$ (Meinzer [1927], USGS gauge 13095500)) emanating from the base of its headwall (Figure 4). Box Canyon was carved into near-horizontal layered flood basalts, named Sand Springs Basalt [Stearns, 1936], with an age of $\sim 95 \mathrm{ka}$ [Tauxe et al.,
2004]. Stearns [1936] postulated that Box Canyon was formed by rock dissolution and that the absence of talus at the head of the canyon in comparison to its sidewalls is evidence of continued dissolution where most of the seepage occurs (Figure 4). Our qualitative observations at the head of the canyon, however, indicate that the rock does not appear mechanically weaker or more weathered than rock found elsewhere in the region. In fact, the most weathered boulders are found well downstream from the channel head. The water that feeds Box Canyon is from the Snake River Plain aquifer, which extends over much of southern Idaho and is composed almost entirely of basalt. Water samples taken by the U.S. Geological Survey from Box Canyon creek and neighboring wells indicate silica concentrations typically ranging from 32 to $35 \mathrm{mg} / \mathrm{L}$, which bracket the saturation value of approximately $33 \mathrm{mg} / \mathrm{L}$ [Faure, 1998] (for dissolved Quartz and amorphous silica at $14^{\circ} \mathrm{C}$ and $\mathrm{pH}=8$, conditions typical of Box Canyon (USGS gauge)). Thus enhanced chemical weathering does not appear to be occurring at the seepage face. Further, there are numerous large springs in close proximity to Box Canyon that are fed by the same basaltic aquifer and do not have canyons associated with them. For example, Thousand Springs is located along the wall of the Snake River canyon about $2 \mathrm{~km}$ from Box Canyon. Thousand Springs has a discharge of $\sim 34 \mathrm{~m}^{3} / \mathrm{s}$, which is more than three times that of Box Canyon, and does not have an alcove. The basalt in Box Canyon breaks down into large $(\sim 1 \mathrm{~m})$ boulders that, without weathering, must be transported away from the canyon head to allow canyon growth. Despite the great discharge of the spring, no measurable amount of sediment is currently being transported through Box Canyon. We have begun to document evidence for a large flood that would have been capable of moving the boulders [Lamb et al., 2004]. This hypothesis is supported by bedrock scours at the rim of the headwall and semicircular talus-free regions at the head of the canyon indicative 


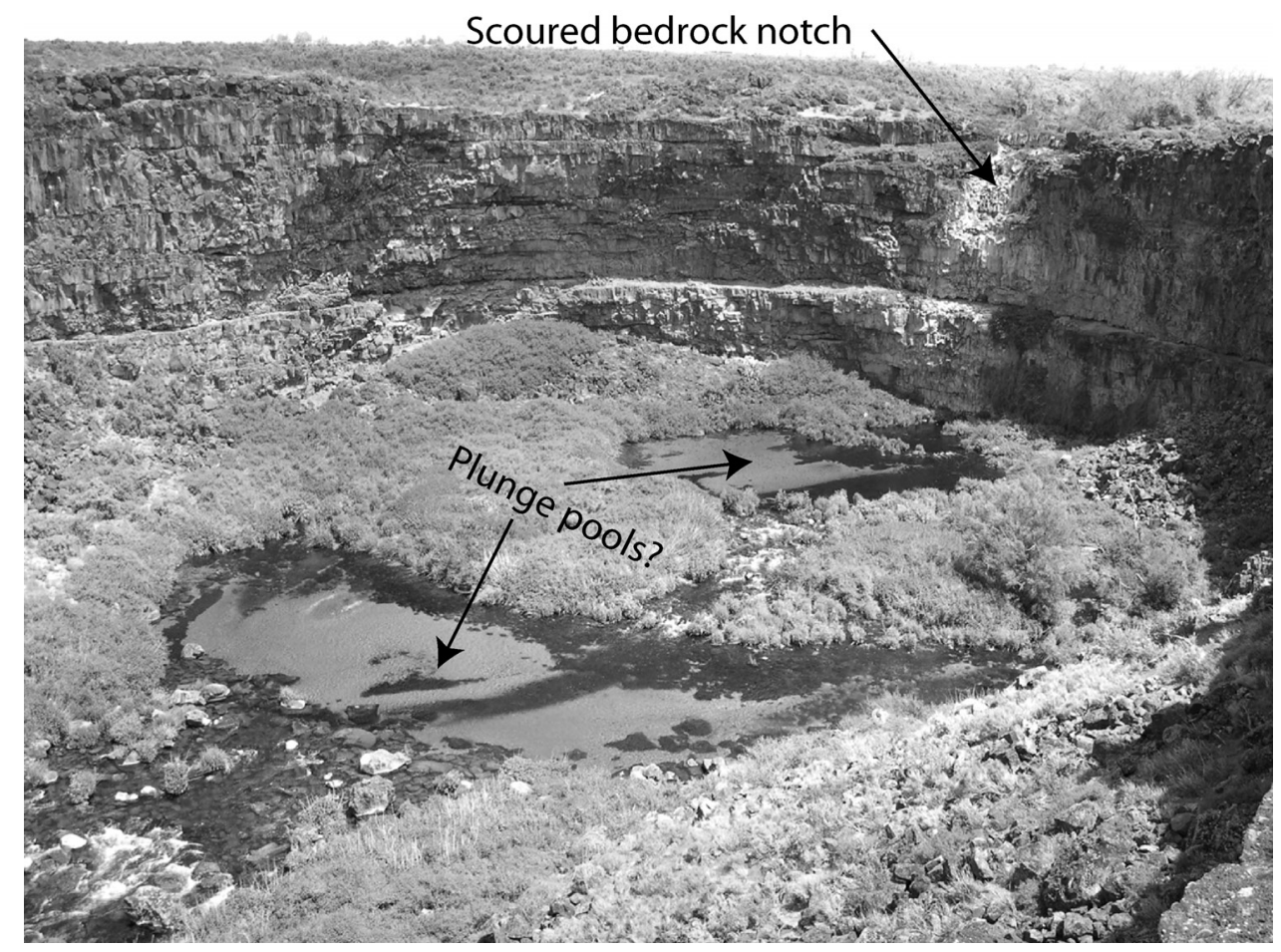

Figure 4. Photograph of the headwall of Box Canyon. Spring water is discharged from the base of the headwall below the water line. Note the absence of talus near the headwall and the semicircular boulderfree regions possibly indicating plunge pools. A scoured notch at the rim of the canyon indicates some overflow in the past. Headwall relief is approximately $40 \mathrm{~m}$.

of plunge pools (Figure 4). The origin of Box Canyon is the topic of our future research, but at this preliminary stage we can conclude that a waterfall origin seems at least as likely as a seepage-erosion origin.

\subsection{Colorado Plateau}

[19] Perhaps the most studied bedrock valleys attributed to seepage erosion are amphitheater-headed canyon tributaries to the Colorado, San Juan, and Escalante Rivers [Laity, 1983; Laity and Malin, 1985; Howard and Kochel, 1988]. These canyons are developed primarily at the lithologic contact where the permeable eolian Navajo sandstone overlies impermeable mudstones and sandstones of the fluvial Kayenta Formation (Figure 5). The case for formation of these valleys by seepage erosion was most strongly argued by Laity and Malin [1985]. In their conceptual model, groundwater flows out along the contact between these two formations because of the contrast in permeability. Weathering and erosion are accelerated where seepage occurs, primarily through salt weathering in which salt crystal growth, associated with groundwater exfiltration and evaporation, causes breakup of the bedrock, leading to focused undermining and alcove development [Laity, 1983]. Some amphitheater heads are near drainage divides, suggesting that minor groundwater flow can be effective in advancing canyon headwalls. Navajo sandstone blocks appear to break down easily to sand once dislodged from cliffs, given the limited amount of coarse debris on canyon floors. This absence of coarse load might allow spring flows or possibly wind to carry away residual sand.
[20] Although we agree that direct evidence for groundwater seepage and seepage weathering at the NavajoKayenta contact is clear, the relative importance of seepage processes versus surface flow processes in setting both valley morphology and headwall retreat rate is ambiguous. Howard [1988, 1994] and Howard and Kochel [1988] provide detailed reviews of evidence for and against a dominant role of seepage erosion in the formation of these valleys. Here, on the basis of our field observations, we further demonstrate the importance of overland flow in transporting sediment and eroding bedrock in this arid environment, and the role of lithologic controls in canyon formation.

[21] Flash flood discharges caused by rapid surface flow across the bedrock uplands greatly exceed spring flows. For example, in three years of monitoring, Dick et al. [1997] measured a flash flood discharge of $\sim 0.9 \mathrm{~m}^{3} / \mathrm{s}$ from $\sim 1 \mathrm{~km}^{2}$ drainage area in this region. Spring discharges from the Navajo sandstone are nearly three orders of magnitude smaller, with maximum measured flows from about $0.001 \mathrm{~m}^{3} / \mathrm{s}$ [Gregory, 1916] to $0.003 \mathrm{~m}^{3} / \mathrm{s}$ [Laity and Malin, 1985]. The strong role of precipitation runoff in transporting sediment is illustrated by the dramatic headcut advance of an interior channel (i.e., arroyo) that occurred in a tributary of Toenlushushe Canyon, Arizona between 1985 and 2004 (Figure 6). The arroyo incised into primarily fine alluvial sediment that was probably deposited during the aggradational epoch of the present arroyo cycle that ended by about 1880 [Cooke and Reeves, 1976]. This aggradation was followed throughout much of the Southwest by deep incision. On the basis of measurements we made from 
A.
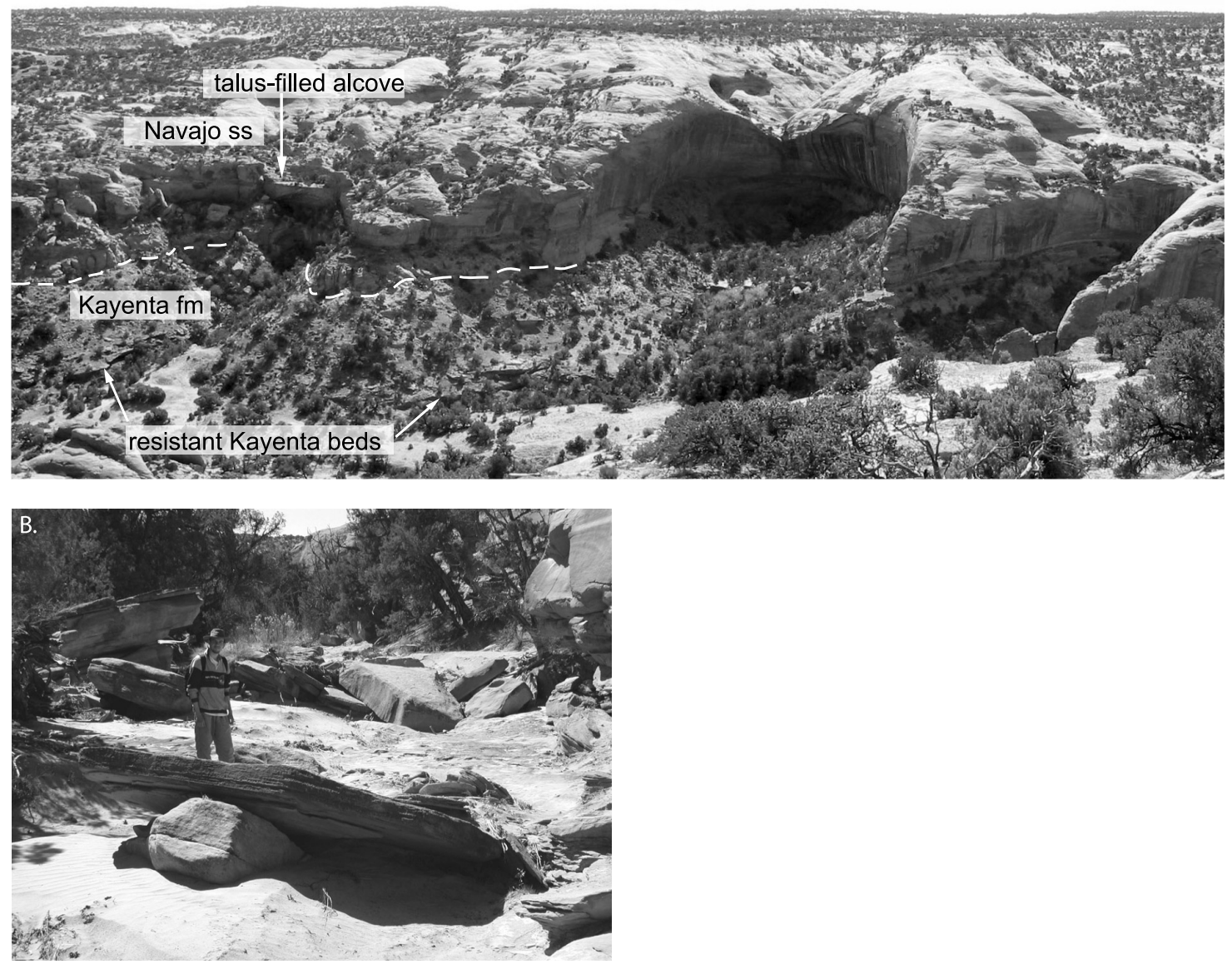

Figure 5. (a) Panoramic view into a large alcove $\sim 400 \mathrm{~m}$ east of Wildcat Seep in Horseshoe Canyon (Head Spur Quadrangle, Utah). The contact between the eolian Navajo sandstone above and the fluvial Kayenta formation below is marked; note that the valley bottoms downstream of the alcoves are significantly inset into the Kayenta formation due to fluvial channel incision into both weak mudstones and resistant fluvial sandstones that form ledges. These resistant Kayenta beds form large boulders that the fluvial channels transport in large flash floods, as indicated in Figure 5b. Also note that the fluvial channel above the well-developed alcove has incised significantly into the Navajo sandstone (making a vshaped notch) and that the headwall with little drainage area to the left is filled in with collapsed talus that has not been excavated. (b) Large, primarily Kayenta boulders in the fluvial channel a short distance downstream of the alcove at Wildcat Seep. Note the imbricated stacking of the slabs, indicating fluvial transport.

aerial photographs and topographic maps, the $\sim 18 \mathrm{~m}$ high headcut progressed about $400 \mathrm{~m}$ over the 19 years between pictures (Figure 6). Simple hydraulic calculations suggest that a $0.003 \mathrm{~m}^{3} / \mathrm{s}$ spring flow would only fill the arroyo with approximately $1 \mathrm{~mm}$ of water (neglecting infiltration and evaporation and using Manning's equation with $n=0.03$, slope of 0.02 , and arroyo width of $48 \mathrm{~m}$ measured from U.S. Geological Survey quadrangle). Such a flow could not transport even the fine sand $(\sim 0.25 \mathrm{~mm})$ found on the valley floor Buffington and Montgomery, 1997]. In order for seepage flow with a constant discharge to transport the required sediment flux, the flow depth must exceed $\sim 6.5 \mathrm{~cm}$ (based on Meyer-Peter and Muller's [1948] equation for bed load transport, recently revised by Wong [2006], assuming a rectangular channel cross section and a minimum average transport rate of $3.7 \times 10^{-4} \mathrm{~m}^{3} / \mathrm{s}$ calculated from the total volume of sediment, $2.2 \times 10^{5} \mathrm{~m}^{3}$, eroded over a maximum time of 19 years. The volume of eroded sediment was calculated from the arroyo dimensions $(18 \mathrm{~m} \times 400 \mathrm{~m} \times 48 \mathrm{~m})$ assuming a porosity of 0.35 .). The required sediment flux could only be achieved by the observed seepage discharge if the channel width was less than $9.8 \mathrm{~cm}$. A channel with this aspect ratio, however, is unreasonable based on our observations of typical spring-fed channels which have width-to-depth ratios much larger than 2 . Furthermore, meter-scale boulders in multiboulder groupings are observed on the bed of the gully (Figure 6c), suggesting flows capable of transporting clasts of this size. The arroyo has a contributing drainage area of about $0.8 \mathrm{~km}^{2}$ from two washes upslope of the canyon headwall. The inability of spring flow to transport significant amounts of fine sand, in contrast to the inferred transport of meter-scale boulders, suggests that flash floods from 

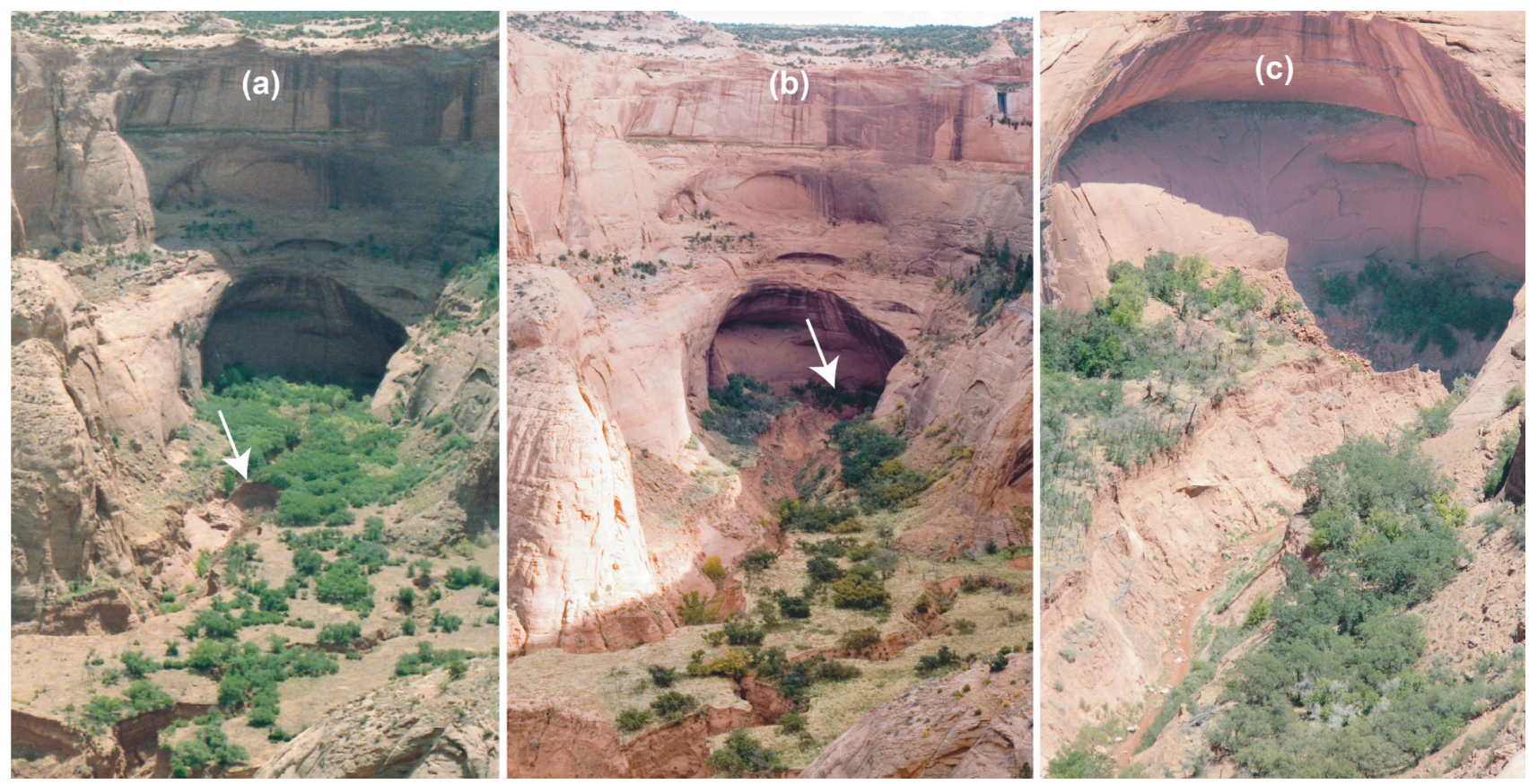

Figure 6. Erosion of alluvial fill in a tributary to Toenleshushe Canyon, Navajo Indian Reservation, Arizona. (a) View of valley and alcove headwall in 1985 . Note the densely vegetated and nearly undissected alluvial fill near the headwall. (b) View in 2004, showing extensive removal of alluvial fill and vegetation near the headwall. Note that viewpoints are slightly different. White arrows mark the location of the interior headwall. (c) Detail of alcove headwall in 2004. Talus has been reexposed in the headwall, and meter-scale boulders occur within the entrenched channel. The headwall is centered at $36.669^{\circ} \mathrm{N}$ and $110.776^{\circ} \mathrm{W}$ on the $7.5^{\prime}$ Inscription House Quadrangle.

summer thunderstorms are responsible for most of the observed sediment excavation.

[22] Amphitheater heads that drain moderate to large surface areas (where significant quantities of surface runoff can occur) typically have plunge pools associated with waterfalls. Figure 7 shows a survey of a typical alcove in Horseshoe Canyon, Utah, with nearly $30 \mathrm{~m}$ of overhang. The slope from the point of maximum overhang down to the basal plunge pool is talus covered and at the angle of repose for noncohesive material. Although the plunge pools are significantly smaller in diameter than the overall amphitheaters, their incision may enable retreat of the much wider canyon headwall by removing the surrounding sediment and talus. Figure 8 illustrates conceptually how vertical plunge pool incision will undermine the angle of repose apron on the seepage face, removing sediment and perhaps leading to deeper undermining of the overlying bedrock and its eventual collapse. This model still requires the formation of an angle of repose slope, which could come about from seepage weathering and collapse of material from above. However, undermining could also occur simply because of recessive weathering of Kayenta mudstone layers. In this way it is at least plausible that the amphitheater width is significantly wider than the plunge pool due to undermining unrelated to seepage.

[23] Ultimately, to move sediment out of the channel, the downstream channel must remain steep enough to transport the sediment; this requires that alcove retreat be tied to incision of the downstream channel [Howard and McLane, 1988]. If seepage erosion alone were driving headwall retreat, the zone of maximum seepage and recession would be at the valley floor, which is rarely the case (e.g., Figure 7). Many of the fluvial channels just downstream of alcoves have incised into resistant beds of the Kayenta formation (Figure 5). These channels are commonly steep, such that boulders that fall onto the canyon floor or are excavated from the channel bed can be effectively removed by flash floods.

[24] The particular stratigraphy of nearly horizontal, permeable, and relatively unjointed (hence relatively strong to slope collapse) but easily weathered sandstone (Navajo formation) overlying an impermeable, mechanically weak strata (Kayenta formation) are essential to the emergence of the distinct canyons. Laity and Malin [1985] suggested that tributaries on the east side of the Escalante do not have amphitheater heads (in comparison to valleys on the west side) because, due to the dip of the Kayenta-Navajo contact, little groundwater flow is directed to the valley heads. Given the sensitivity of canyon morphology to exposure of Kayenta-Navajo contact, this comparison is incomplete because the eastside tributaries expose the recessive and impermeable upper Kayenta formation, while the westside tributaries do not.

[25] These observations suggest that the morphology of these canyons likely does not depend uniquely on seepage erosion processes. There are amphitheater valleys with little upland runoff and with groundwater seepage, where salt weathering forms local alcoves and mostly likely contributes to headwall retreat. However, in many instances, if not all, runoff in channels from overland flow is a contributor 
and in some cases may dominate the channel incision through plunge pool erosion and transport of collapsed debris. The particular geologic framework and the possibility of significant contributions from both surface runoff and seepage suggest that these canyons are at present an ambiguous analog for interpreting valley forming processes elsewhere.

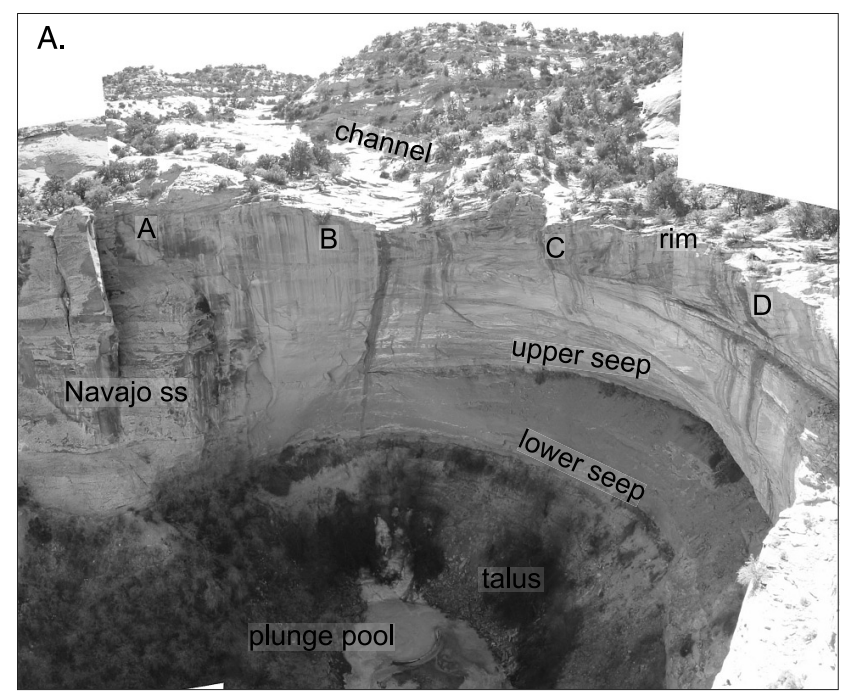

B.
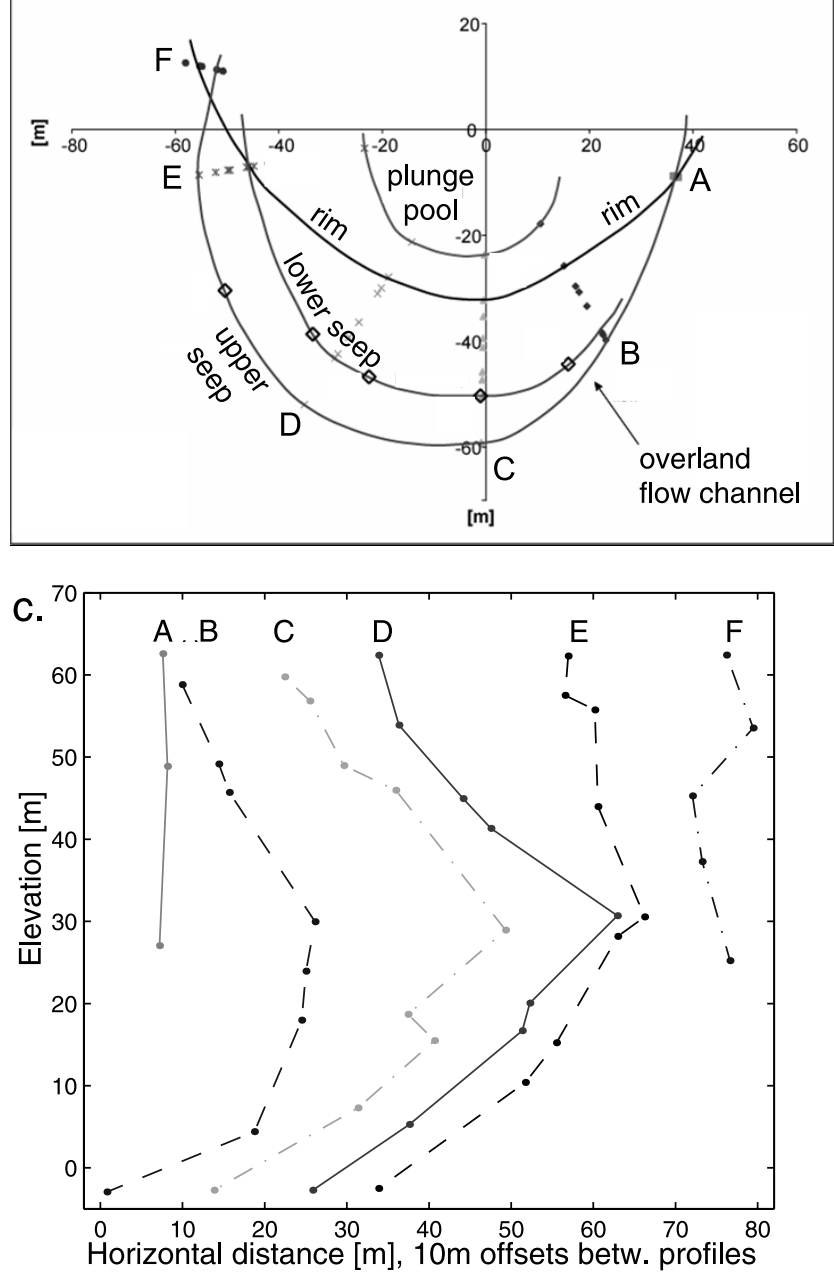

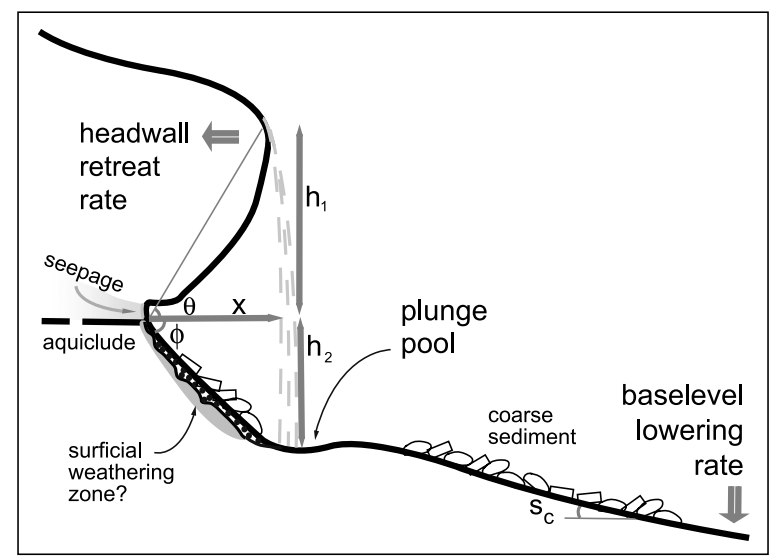

Figure 8. Conceptual model of some likely controls on alcove morphology and headwall retreat rate at the Navajo/ Kayenta contact. Headwall morphology is dictated by caprock strength (maximum $\theta$ ) and thickness $\left(h_{1}\right)$, which sets the critical overhang distance $(x)$, plus the maximum stable angle of the weathered, typically sediment-covered zone $(\varphi)$, in turn is set by the angle of repose for sediment or the residual strength of the weathered rock. The combination of overhang required for failure $(x)$ and the critical slope $(\varphi)$ of the seepage zone dictate the depth of incision below the upper seep required for headwall retreat $\left(h_{2}\right)$, which is likely accomplished by plunge-pool scour and fluvial erosion. Ultimately, plunge pool downcutting may be limited by the base level lowering rate of the downstream fluvial channel because the channel must maintain a critical slope $\left(S_{c}\right)$ that enables the transport of coarse sediment derived from incremental headwall collapse and downstream channel erosion.

\subsection{Hawaiian Islands}

[26] The most cited examples of amphitheater-headed valleys in basalt are on the windward, wet sides of the Hawaiian Islands [Hinds, 1925; Stearns and Macdonald, 1946; Macdonald et al., 1983; Kochel et al., 1985; Baker,

Figure 7. (a) Panoramic photograph of Burro Seep alcove of Horseshoe Canyon (Head Spur Quadrangle, Utah), just east of Canyonlands National Park. The contact between the eolian Navajo Sandstone above and the fluvial Kayenta formation below occurs at the lower seep level, significantly above the valley bottom. The plunge pool is ice covered because of active seepage in this March 2002 photograph. Field observations verify that the talus-covered ramp is at the angle of repose for noncohesive material and is symmetric around the plunge pool. Drainage area above the alcove is $1.2 \mathrm{~km}^{2}$. (b) Surveyed morphology of the alcove, shown in plan view. Lines A-E correspond to surveyed cross sections in Figure 7c. Measurements were made by Simon Brocklehurst. (c) Surveyed cross-section profiles of the alcove, showing vertical valley walls on the sides (profiles $\mathrm{A}$ and $\mathrm{F}$ ) and nearly $30 \mathrm{~m}$ of overhang in the center (D). The overhang is greatest in the center of the alcove and is notably offset from the entrance point of the main overland flow channel, although the current zone of most active seepage, indicated by ice on the talus ramp, occurs directly under the channel. 


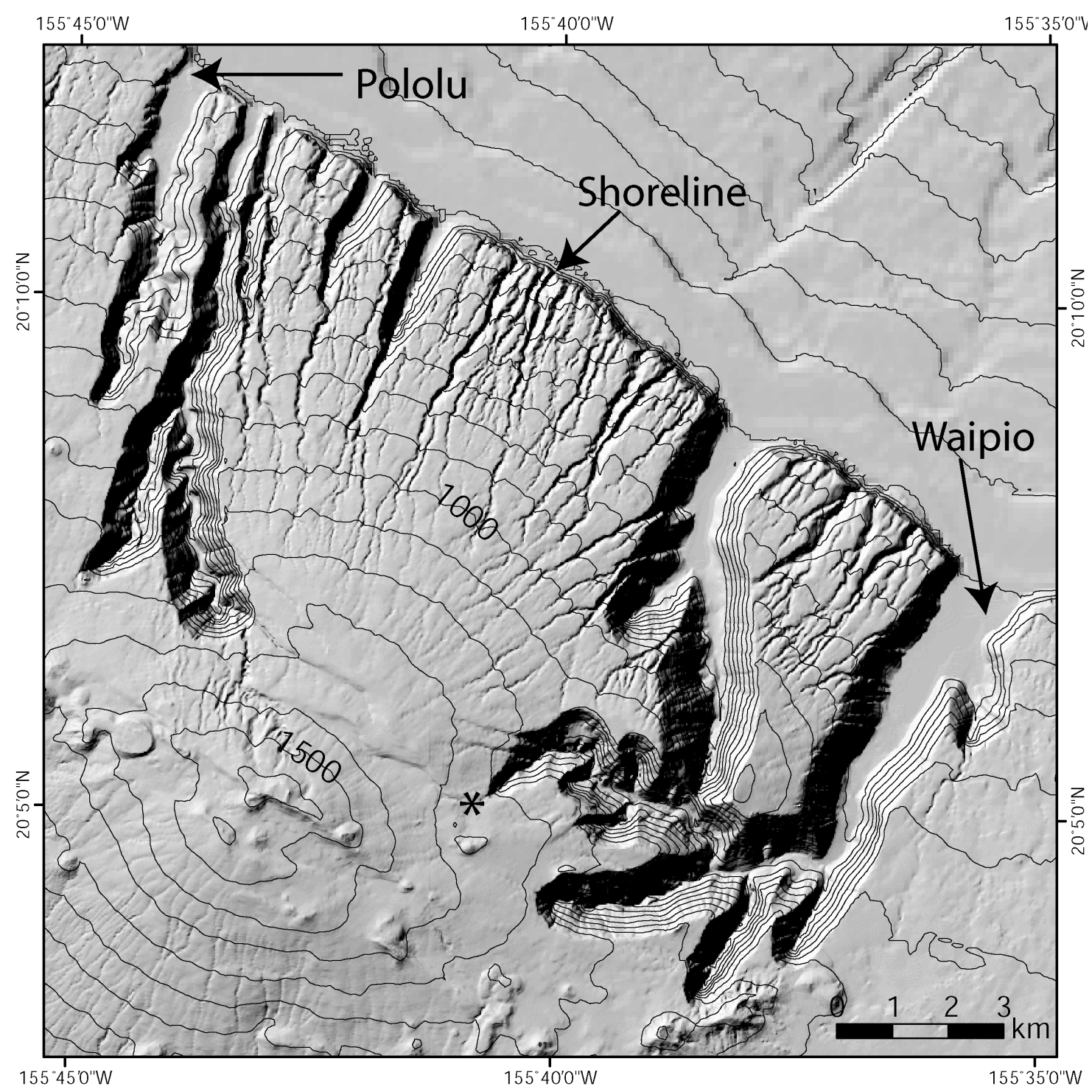

Figure 9. Shaded relief map of $10 \mathrm{~m}$ resolution topographic data and $90 \mathrm{~m}$ resolution bathymetric data of the Kohala region of Hawaii. The contour interval is $100 \mathrm{~m}$. The $1000 \mathrm{~m}$ and $15000 \mathrm{~m}$ contours are labeled. Data are from U.S. Geological Survey, Monterey Bay Aquarium Research Institute, and U.S. Army Corps of Engineers. The asterisk marks the location of the headwall shown in Figure 10.

1990; Howard et al., 1994; Craddock and Howard, 2002; M. P. Lamb et al., Formation of amphitheatre-headed valleys by waterfall erosion after large-scale slumping on Hawaii, submitted to Geological Society of America Bulletin, 2006, hereinafter referred to as Lamb et al., submitted manuscript, 2006]. Some of the most spectacular are the Kohala valleys on the island of Hawaii (Figure 9). These valleys have U-shaped cross sections in their lower reaches, and most of the headwalls are steep and semicircular in planform. In contrast, smaller valleys that run along side of and often drain into the larger canyons have more V-shaped heads in planform and lack steep headwalls.

[27] The similarity of the Kohala amphitheater-headed valleys with those in the Colorado Plateau and in sand boxes (mainly the flat floors and steep headwalls) led Kochel and Piper [1986] and Kochel and Baker [1990] to argue that seepage eroded the Kohala canyons. Building upon earlier suggestions by Wentworth [1928] and Stearns and Macdonald [1946], they proposed that rapid chemical weathering induced by seepage at the intersection between dike-impounded water tables and streambeds caused the formation and subsequent undercutting of knickpoints. These knickpoints carved the valleys by propagating upslope, eventually forming the steep valley headwalls. The smaller valleys were not able to tap groundwater and therefore remained small.

[28] If seepage erosion carved the Hawaiian valleys, springs must have been able to weather and erode the seepage face, as well as transport collapsed talus and boulders out of the valleys. The evidence for such processes is lacking. Well-developed alcoves, secondary porosity, or obviously weathered rocks are rare at valley heads [Howard et al., 1994]. Furthermore, springs have not been found in some valley heads (e.g., Pololu valley [Stearns and Macdonald, 1946]). Where springs occur, the discharges are small and the flows are unable to transport the large 


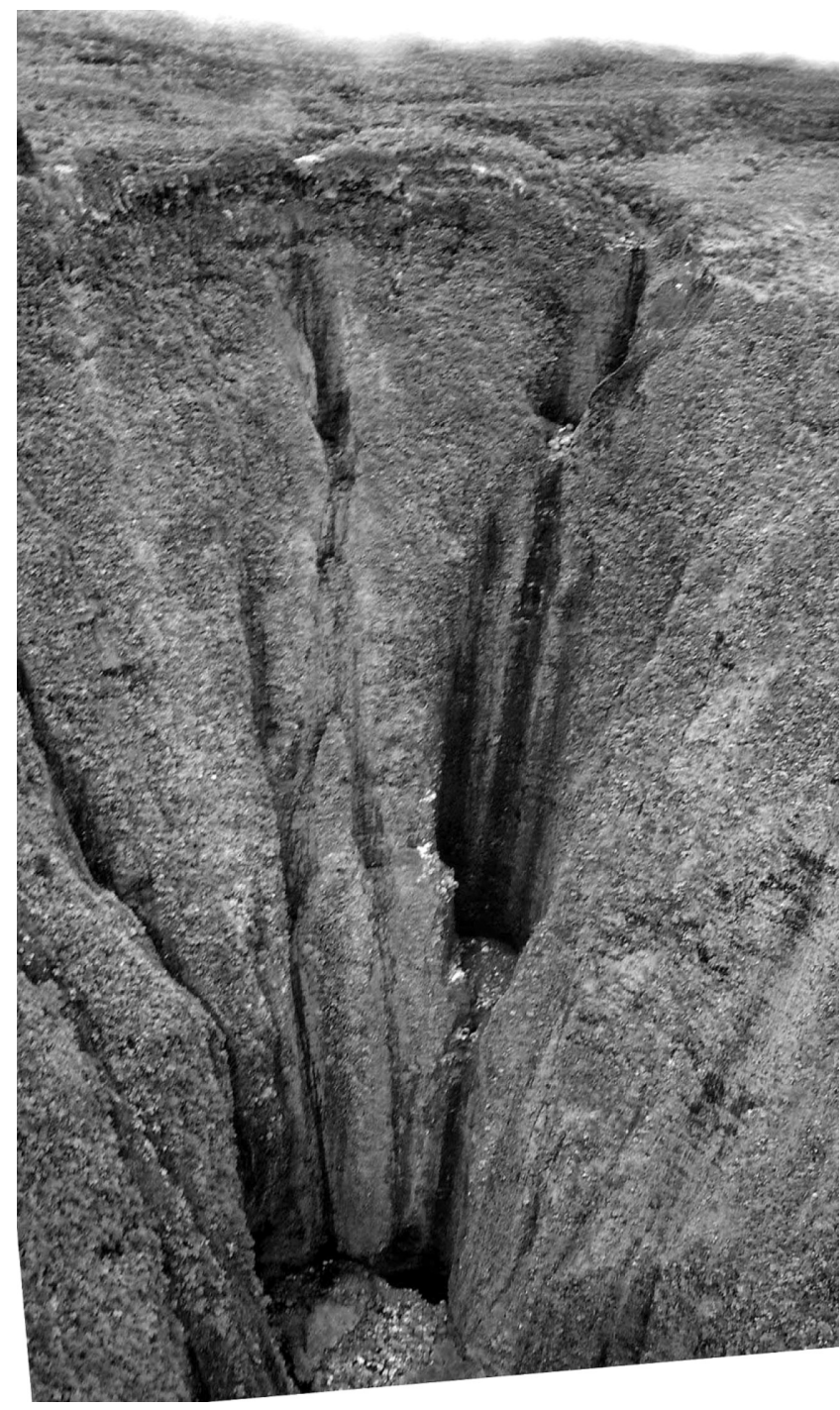

Figure 10. Photographs showing waterfall plunge pools at the head Waipio valley (indicated with an asterisk on Figure 9). Headwall relief is approximately $600 \mathrm{~m}$. Note multiple waterfalls that appear to be vertically eroding plunge pools.

$(\sim 1 \mathrm{~m})$ basalt boulders that accumulate in the channels. For example, Waipio valley (Figure 9) has the greatest number and discharge of springs which range from 0.35 to $0.96 \mathrm{~m}^{3} / \mathrm{s}$, with a cumulative discharge of $2.76 \mathrm{~m}^{3} / \mathrm{s}$ [Stearns and Macdonald, 1946]. These springs, however, are dwarfed by Wailoa stream, which flows through the main section of Waipio valley with a mean annual peak discharge of $120 \mathrm{~m}^{3} / \mathrm{s}$ and a maximum recorded peak discharge of $241 \mathrm{~m}^{3} / \mathrm{s}$ (USGS gauge 1632200).

[29] Hawaiian amphitheater-headed valleys typically have waterfalls at their headwalls [Stearns and Vaksvik, 1935; Macdonald et al., 1983]. These waterfalls are commonly stepped and appear to cause substantial erosion as indicated by the deep plunge pools interrupting the cascading falls (Figure 10) [Howard et al., 1994]. Multiple active waterfalls along with mass wasting at the headwall could allow for the retreat of a headwall that is much wider than any individual waterfall [Stearns, 1985]. The retreat of a wide headwall, mass wasting of valley sidewalls, and the radial drainage pattern are all potentially important in capturing neighboring streams [Macdonald et al., 1983]. The flat floors near the valley mouths, while previously argued to indicate groundwater sapping [Kochel and Piper, 1986; Kochel and Baker, 1990], are the result of alluviation of valley floors following island subsidence [Stearns, 1985; Moore and Clague, 1992]. Lamb et al. [2005, submitted manuscript, 2006] combined these observations and proposed that the Kohala valleys formed from upstream propagation of huge knickpoints due to waterfall erosion, rather than seepage erosion. These knickpoints were most likely initiated by the headscarp of a huge flank collapse of Kohala volcano, the Pololu Slump [Moore et al., 1994; Smith et al., 2002], expressed as the present-day $\sim 400 \mathrm{~m}$ sea cliffs. Smaller valleys might not have developed into amphitheater-headed valleys because they have smaller drainage areas contributing to surface runoff [Lamb et al., 2005, submitted manuscript, 2006].

\section{Amphitheater-Headed Bedrock Canyons: Alternative Interpretations}

[30] Amphitheater-headed valleys can arise from other processes in the absence of seepage, such as upstream advancing waterfalls where plunge pool erosion and mass wasting drive headwall retreat. Plunge pool processes in layered sediments are known to result in knickpoints [e.g., Holland and Pickup, 1976; Robinson and Hanson, 1996; Hanson et al., 1997; Bennett et al., 2000; Bennett and Casali, 2001]. These knickpoints can develop an amphitheater form as they advance upstream. For example, in the welded ash of the Ka'u desert, Hawaii, amphitheater-headed canyons have formed exclusively from plunge pool undermining by surface runoff [Craddock et al., 2005] (Figure 11). Headwall propagation by waterfall erosion also occurs in more resistant rock [Rosenblum and Anderson, 1994; Seidl et al., 1994; Yoshida and Ikeda, 1999; Bollaert

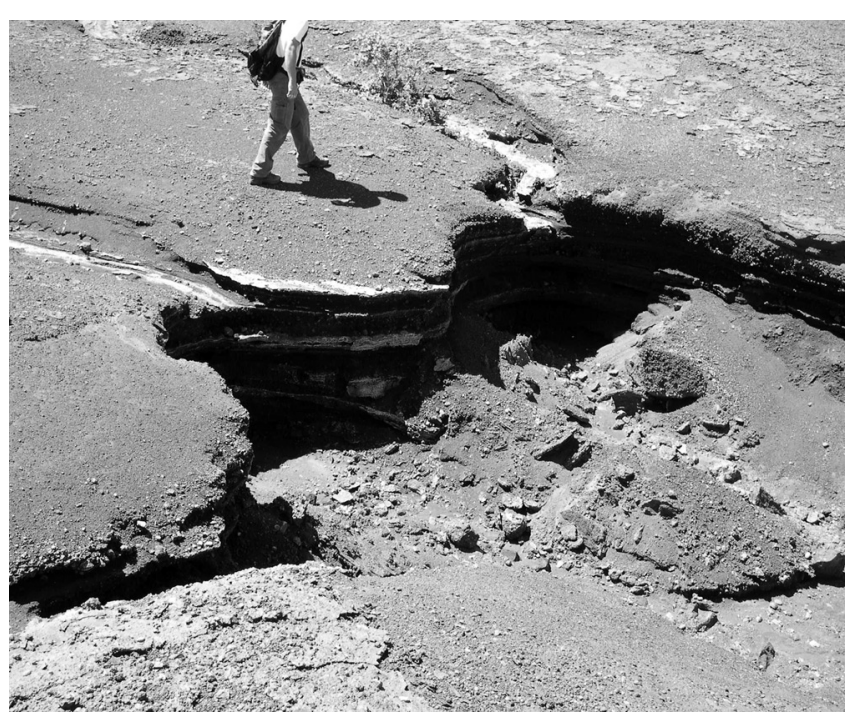

Figure 11. Photograph of small amphitheater-headed canyons eroded into layers of welded ash in the Ka'u desert on the island of Hawaii. 


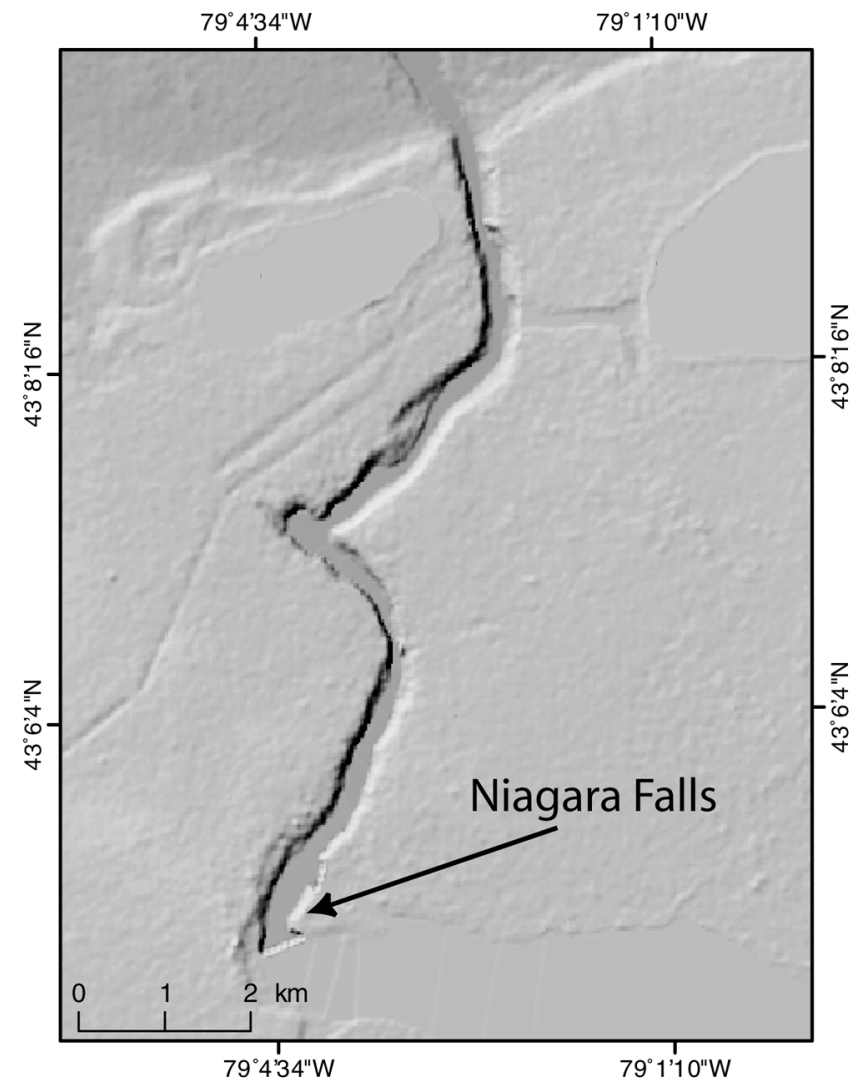

Figure 12. Shaded relief map of $30 \mathrm{~m}$ SRTM topographic data (U.S. Geological Survey) of Niagara Falls. Lake Erie is to the north. Note that at this resolution the channel upstream of the waterfall is relatively indecipherable, such that the falls could be taken as the headwall of an amphitheater-headed canyon.

and Schleiss, 2003; Hayakawa and Matsukura, 2003; Bishop et al., 2005; Crosby and Whipple, 2006]. For example, Niagara falls retreats upstream as the resistant limestone caprock fails due to plunge pool undercutting of the underlying mudstone [Gilbert, 1907], leading to an amphitheater-headed valley (Figure 12). Examples in basalt are the series of amphitheater-headed tributaries of the Snake River, Idaho, (e.g., Blue Lakes Canyon) formed by the Eden Channel of the gigantic Bonneville Flood spilling over the walls of the Snake River Canyon [Malde, 1968; O'Connor, 1993].

[31] In the aforementioned examples of amphitheaterheaded valleys, an initial near-vertical face was imposed on the valleys by some external source, and therefore might be a necessary condition for the formation of amphitheaterheaded valleys. For example, Box Canyon, as well as the canyons of the Colorado Plateau, grew outward from the deeply incised river canyons of the Snake River and the Colorado and San Juan Rivers, respectively. The Kohala valleys of Hawaii likely evolved from the steep headwall of the Pololu Slump (Lamb et al., submitted manuscript, 2006). A near vertical headwall was typically used as the lower boundary condition in seepage-erosion sand box experiments [Kochel et al., 1985; Howard and McLane, 1988]. On Mars, such knickpoints might be induced by the wall of a deeply incised river canyon or impact crater.
[32] Perhaps a more important factor leading to an amphitheater head is the stability of the headwall relative to the resistance of the material to incision, rather than any particular erosion process, be it seepage or plunge pool erosion. One of the most obvious similarities between all of the amphitheater-headed valleys cited, whether carved in basalt or sediments, by seepage or waterfall, is that they have been eroded into a material consisting of relatively horizontal beds of varying strength. This configuration is relatively resistant to vertical incision, in that eventually a strong bed will need to be cut through. On the other hand, such materials are relatively susceptible to lateral retreat by backwasting of a near vertical face because a vertical face exposes weaker beds, which can then be undercut. The near horizontal layering also promotes stability of a vertical face, which leads to a more amphitheater-like shape [Dunne, 1990]. Vertical variations in rock strength are well illustrated in the layered sandstones and mudstones of the Colorado Plateau. In the layered volcanic rocks of Hawaii and Box Canyon there might be subtle differences in rock strength for the different lava flows, but this is less obvious. However, basalts have an inherent anisotropy in their resistance to erosion because of fracturing. While basalt is relatively resistant to vertical incision by fluvial processes [Sklar and Dietrich, 2001], erosion by lateral backwasting might be more effective because vertical columnar fractures allow the face to easily collapse (e.g., Figure 4). Stearns [1985] also suggested that vertical jointing and horizontal bedding in basalt makes it more prone to stand as a vertical headwall in Hawaii. In weak sedimentary rocks or sediments, subtle changes in grain size, such as a cohesive layer or a gravel lag, or vegetation cover might favor lateral retreat over vertical incision, and tend to produce a steep headwall. Even in seepage erosion experiments that used a homogeneous sand substrate [e.g., Howard and McLane, 1988], there was likely a vertical variation in the resistance to erosion because surface tension of pore water acted to provide cohesion above the seepage zone, allowing a near vertical headwall.

[33] In some cases the rate of headwall retreat might be governed by the loss of strength and failure of the vertical face rather than any particular hydraulic process. Such a mechanism has been proposed for the formation of amphitheater-headed canyons along the Australian escarpment [Young, 1985; Seidl et al., 1996; Weissel and Seidl, 1997]. Seepage or surface flow might then only play a role in evacuating collapsed material that would otherwise form a talus slope and buttress the headwall from further collapse.

\section{Seepage Erosion on Mars?}

[34] Involvement of groundwater seepage in excavation of valley networks on the cratered highlands of Mars has been postulated in numerous studies [e.g., Pieri, 1980; Carr and Clow, 1981; Baker and Partridge, 1986; Goldspiel and Squyres, 2000; Grant, 2000; Gulick, 2001]. Difficulties in finding mechanisms for producing an atmosphere early in Martian history capable of supporting precipitation and runoff led to early suggestions that valley network erosion could be due to mobilization of water originally stored in the regolith. Erosion of valleys, however, requires volumes of water at least 100 times the volume of sediment removed 
in cutting the valley, even in the case of cohesionless sands [Howard and McLane, 1988]. For cohesive soils or indurated rock, cumulative discharges greater than $10^{5}$ times valley volume is required in terrestrial valley networks to accomplish weathering, bed erosion, and transport of sediment through the valley network [Howard, 1988; Goldspiel and Squyres, 1991]. This large water demand led others to suggest that flows through the valley networks might have been supplied hydrothermally from volcanic intrusions [Gulick, 1998, 2001] or from crater impacts [Tanaka et al., 1998]. Basal melting of the south polar cap has also been proposed as a source of water for groundwater seepage to cut valley networks [Clifford and Parker, 2001]. Carr [2002] notes, however, that many valley networks occur at elevations too high for this to have been a contributing source of water. Some valley networks with amphitheater headwalls originate high on the outer rims of crater basins, so that, if they were formed by seepage erosion, water sources had to be very local and derived from precipitation [Grant, 2000]. Indeed, recent acquisition of high-resolution images suggests that flow magnitudes and drainage patterns most likely required precipitation [Craddock and Howard, 2002; Malin and Edgett, 2003; Moore et al., 2003; Mangold et al., 2004; Irwin et al., 2005; Moore and Howard, 2005].

[35] Low Martian drainage densities have also been suggested to be indicative of seepage erosion. The assumption is that a large drainage area per unit length of channel (the inverse of drainage density) implies a large discharge is required for channel cutting, and this would be consistent with the relatively weak process of spring driven incision. Measurements of drainage density based upon Viking and Mariner 9 images with resolutions $\sim 200 \mathrm{~m} /$ pixel resulted in estimated drainage densities of $\sim 0.02 \mathrm{~km}^{-1}$ [Carr and Chuang, 1997]. Recent measurements based upon higherresolution images from the Narrow Angle Mars Observer Camera (MOC NA) and the Mars Observer Laser Altimeter (MOLA) have increased maximum estimated drainage densities to $\sim 0.1 \mathrm{~km}^{-1}$, which approaches the range of terrestrial drainage densities [Irwin and Howard, 2002; Hynek and Phillips, 2003]. Rather than being indicative of seepage, the relatively low drainage densities might arise from high permeability of the impact-generated regolith on early Mars, abundant small depressions from impacts [Hartmann et al., 2001] that encourage infiltration, and modification of the valleys by eolian infilling, mass wasting, and impact gardening subsequent to the time period of active flows [Williams and Phillips, 2001; Craddock and Howard, 2002; Irwin and Howard, 2002].

[36] Even if one assumes that amphitheater-headed valleys are indicators of seepage erosion, a morphologic analysis is hampered on Mars by image resolution and postincision degradation by mass wasting. Images of the Martian surface from missions through the Viking Orbiters produced near-global coverage at resolutions generally between 200 and $300 \mathrm{~m} /$ pixel. At such resolution many valley networks appeared to terminate at abrupt headwalls. In more recent higher-resolution images from Mars Global Surveyor, Mars Odyssey, and Mars Express, small tributaries are generally seen to gradually shallow headward, merging progressively with their contributing uplands (Figure 13).

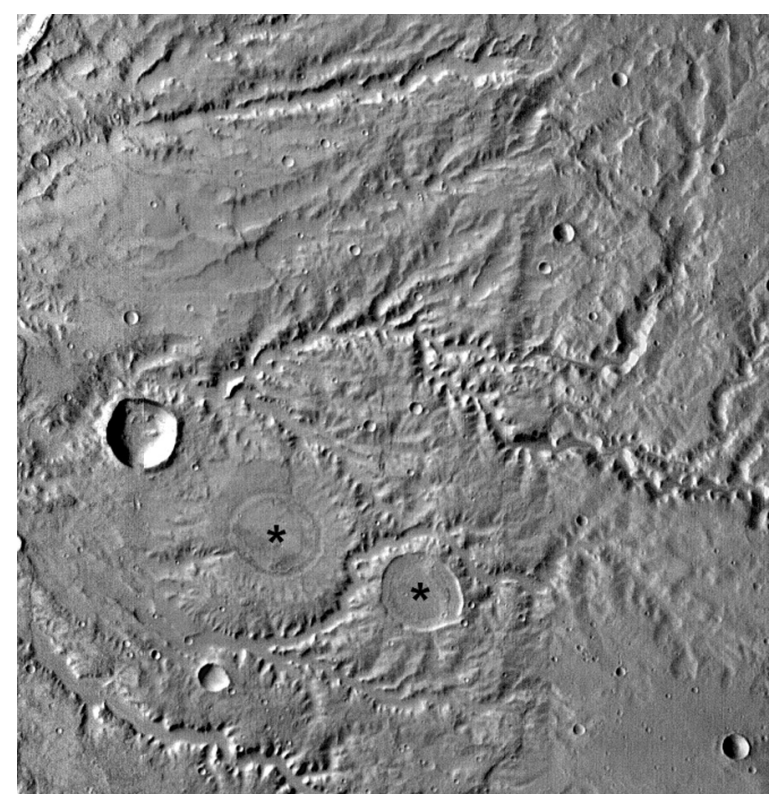

Figure 13. A portion of the Parana Valles Martian valley network. Image width is $63.7 \mathrm{~km}$. Image is centered at about $21.5^{\circ} \mathrm{S}$ and $349.5^{\circ} \mathrm{E}$. Although the larger valleys are deeply incised with steep valley walls, smaller tributaries generally shallow gradually toward their headward end, often merging insensibly with the source upland. Note the two impact craters marked with asterisks that have been eroded to the point that their rims are nearly obliterated. North is to top of image. Shown is a mosaic of portions of THEMIS IR images I01886002, I00825004, I04495002, and I06717002.

[37] Once channel incision ceased on Mars, mass wasting, eolian deposition and erosion, and impact cratering continued to erode and deposit mass, destroying diagnostic features of smaller tributaries. The Nirgal Valles system, long considered to be the type example for a groundwater sapping network on Mars, has been deeply infilled by eolian sediments, as evidenced by the shallow valley headwalls and the abundant megaripples on the valley floor (Figure 1). The valley walls show little evidence of bedrock layering, despite the probable excavation of the valley into layered basaltic flows [Scott and Tanaka, 1986]. Mass wasting processes and impact gardening have apparently relaxed the valley walls until they average about $19^{\circ}$ in steepness. Slope angles less than typical angle of repose slopes $\left(>30^{\circ}\right)$ may have been produced by ice-driven creep [Perron et al., 2003]. As a result of these modifications, many of the local features in terrestrial drainage networks that suggest a seepage-erosion origin cannot be found, including seepage faces and undercut valley headwalls.

[38] Simulations by Howard [1995] of scarp planform evolution showed that valleys formed initially in layered rocks by fluvial erosion (producing scarps with headward canyon terminations that are pointed in planform) can develop rounded amphitheater headwalls if they are subsequently modified by uniform scarp retreat driven by weathering and mass wasting. Hence not only are channel features obscured, but valley morphology can take on a form that appears to be due to seepage erosion, even when it does not occur. This suggests a simple test. Figures 14 and 15 show 


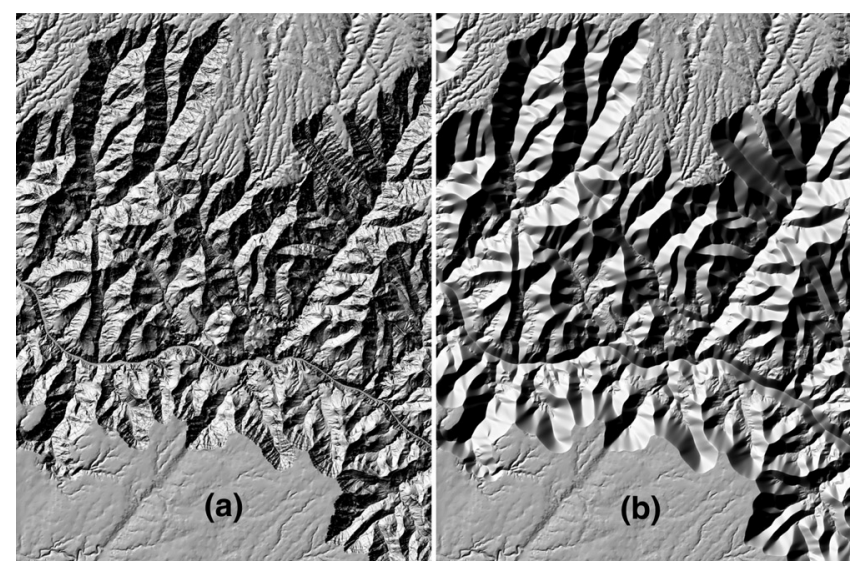

Figure 14. Shaded relief image of portions of the Phantom Ranch, Shiva Temple, Grand Canyon, Bright Angel Point, Kanabounits Spring, and Little Park Lake 7.5' digital $10 \mathrm{~m}$ DEM (a) before and (b) after simulated relaxation of slopes steeper than $20^{\circ}$.

shaded relief images of a portion of the Grand Canyon showing steep tributaries to the Colorado River and the towering cliffs in sandstones and limestones bordering these valleys. Although seepage erosion may play a minor role in valley extension within the Kaibab and Redwall Limestones, the main processes of canyon erosion and extension are runoff erosion and debris flow incision [Webb et al., 1989; Griffiths et al., 2004]. The tributaries on the north side of the Colorado River have eroded farther due to extensive drainage from the highlands north of the Grand Canyon passing over the canyon rim. This asymmetry is due to the gentle southward dip of the Paleozoic sedimentary layers exposed in the upper portions of the canyon. To explore the morphologic effects of mass wasting, we have iteratively modified the digital elevation model (DEM) of this landscape by assuming that the steep rocky slopes greater than $20^{\circ}$ gradually weather, yielding debris that is

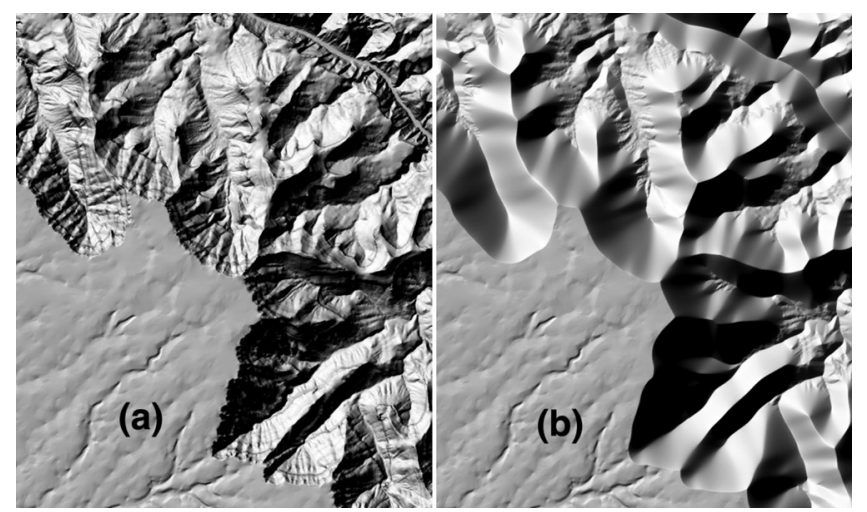

Figure 15. Detail of the lower right corner of Figure 14, showing (a) a shaded relief image of the existing topography (based upon the Phandom Ranch 7.5' $10 \mathrm{~m}$ DEM). (b) Same region after simulated relaxation of steep valley walls to $20^{\circ}$. Note the stubby tributaries, the rounded valley headwalls, and the eradication of the fine-scale drainage network on the steep slopes. Compare Figure 15b with the Martian valley topography shown in Figure 16. transported by mass wasting, with the produced debris accumulating at the base of the slope (conserving total rock volume) until no slope is steeper than $20^{\circ}$. Slopes less than $20^{\circ}$ are unmodified. This modeling is a numerical implementation of the geometrical mass wasting model of Bakker and Le Heux [1952]. The result is that canyon wall tributaries exhibit broad rounded headwalls and narrow infilled valleys. The fine-scale fluvial network on the steep slopes is eradicated (Figure 15). This morphology is very similar to stubby tributaries of Valles Marineris (Figure 16), which have long been attributed to a groundwater-sapping origin. Side slopes of these valleys average about $26^{\circ}$. Similar modifications might have produced the rounded headwalls of the Nirgal Valles system (Figure 1). This simple analysis suggests that subsequent mass wasting has modified the valleys to the extent that any inferences about the formative erosion processes must be speculative.

[39] The proposed groundwater-sapping origin for Martian valley networks is based primarily on the assumption that seepage erosion creates a distinctive morphology, an assumption we have challenged throughout this paper. The surface lithology of Mars consists of volcanic and sedimentary rocks [Malin et al., 1998; Bandfield et al., 2000; Hamilton and Christensen, 2005; Malin and Edgett,

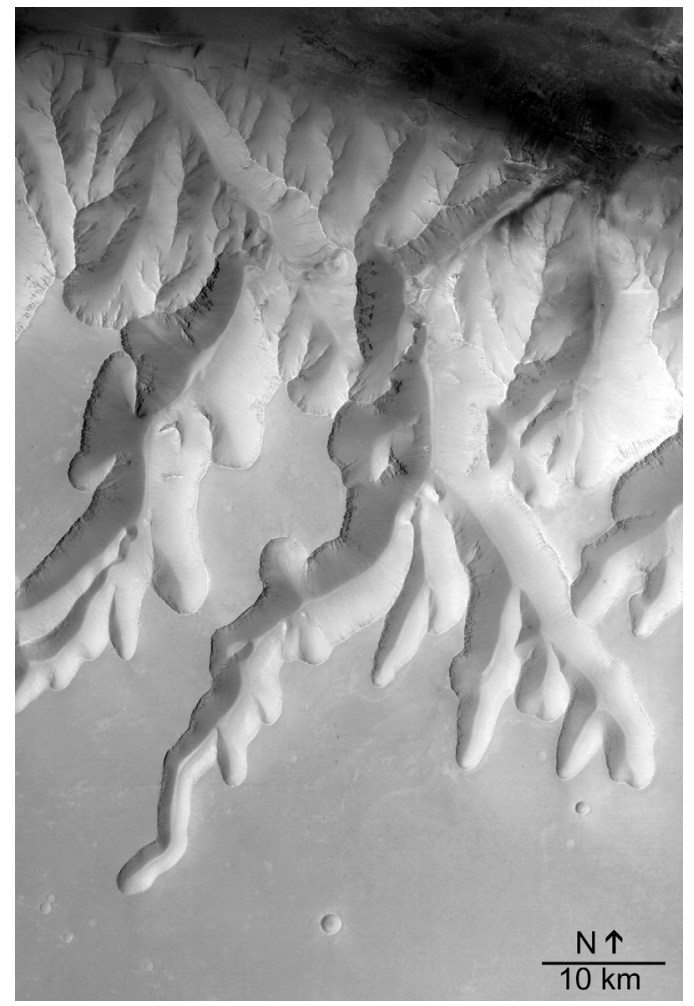

Figure 16. Deeply incised valleys on the south wall of Ius Chasma on Mars, at the western end of Valles Marineris. These valleys are part of Louros Valles. The floor of Ius Chasma is at the north end of the image. Relief from the plateau surface to the chasma floor is about $7 \mathrm{~km}$. Image is located at about $8.5^{\circ} \mathrm{S}$ and $278.8^{\circ} \mathrm{E}$. Image is from Mars Express High Resolution Stereo Camera, orbit H0097, courtesy of the European Space Agency Multimedia Gallery. 
2000]. The evidence for seepage alone carving valleys into volcanic and sedimentary rocks on Earth is ambiguous. A major process limitation in resistant rock is the apparent inability of springs on Earth to transport coarse talus that collapses into the channels. This, however, does not rule out a seepage origin for Martian valleys. For example, if the valleys were carved into sedimentary rock with easily dissolved cement that weathers to fine-grained transportable sediment, or if the bedrock has been pulverized through repeated bolide impacts, creating a cohesionless, relatively fine-grained detrital waste, then a seepage-erosion origin is possible.

\section{Seepage Erosion on Titan?}

[40] The recent discovery of branching valley networks on Titan, some of which appear to have short, stubby tributaries, has led to suggestions that seepage processes played a role in their formation [Tomasko et al., 2005]. The stubby appearance of the valleys on Titan is based mainly on albedo contrasts in images, however; the available topographic data are not sufficiently detailed to determine whether the valleys have amphitheater heads. Some of these valley networks have morphologic characteristics that are inconsistent with spring-fed fluid discharge, including radial drainage patterns formed on isolated peaks in the topography and tributaries that extend to within $200 \mathrm{~m}$ of one another on opposite sides of a topographic divide [Perron et al., 2006].

[41] Erosion mechanisms on Titan involve combinations of materials that are unfamiliar on Earth and Mars: Titan's water ice crust [Schubert et al., 1986] at the surface temperature of $94 \mathrm{~K}$ has strength [Durham et al., 1983; Cuda and Ash, 1984] comparable to terrestrial bedrock [Goodman, 1989]. The volatile in Titan's "hydrologic" cycle is probably methane, which comprises several percent of Titan's thick atmosphere and is stable in liquid form at its surface. Springs on Titan probably do not cause significant chemical erosion because the solubility of water ice in liquid methane is extremely small [Rest et al., 1990; Lorenz and Lunine, 1996]. Chemical weathering rates on Titan could be higher if the surface material contains a significant fraction of hydrated ammonia compounds [Lorenz and Lunine, 1996], but no signature of these compounds has yet been identified in surface spectra.

[42] Recent ground-based [e.g., Griffith et al., 2000; Brown et al., 2002] and spacecraft [e.g., Porco et al., 2005; Griffith et al., 2005] observations of Titan have documented the development and rapid dissipation of tropospheric clouds, which suggests an active methane cycle involving rainfall. Seepage erosion may have contributed to the formation of the valley networks on Titan if the surface material is poorly consolidated, but it seems likely that surface runoff associated with methane precipitation has also played a role, perhaps eroding water ice bedrock [Collins, 2005] and transporting sediment [Perron et al., 2006] by processes similar to those on Earth.

\section{Conclusions}

[43] Mechanistic evidence for springs eroding valleys with distinctive morphologies into rock is sparse and inconclusive. Lithology has been shown to be a first-order control on whether and how seepage erosion might occur. In unconsolidated, permeable sediments groundwater seepage can be sufficient to both erode the valley head and remove the eroded material, sometimes (but not always) resulting in valleys with amphitheater heads. In weakly consolidated sedimentary rocks, groundwater might control the shape and perhaps the rate of valley formation. However, it is also possible that seepage erosion plays a secondary role to runoff processes such as plunge pool erosion, or to mechanical processes such as loss of strength and mass failure. Sediment must be evacuated from the valley in order for retreat of the headwall to continue, which seems to require surface runoff for most cases on Earth. In basaltic valleys, there is no clear evidence that seepage causes significant erosion. Instead, plunge pools and large boulders that line the valley bottoms support erosion and excavation by surface runoff. While we know of no unambiguous case of seepage eroding an amphitheater-headed valley in resistant rock, several examples exist of valley formation by runoff and mass wasting processes in the absence of seepage erosion. Instead of a particular hydraulic process, amphitheater heads might instead be indicative of a substrate that, because of rock strength and fracture orientation, is relatively unstable to headwall retreat, but resistant to incision at the rim of the headwall. Amphitheater valley heads should not be used as a diagnostic indicator of seepage erosion on Earth, Mars or elsewhere because of the present uncertainty in the ability of seepage to independently erode bedrock valleys and the fact that mass wasting and runoff processes can (also) carve amphitheater-headed valleys.

[44] Our analysis, however, does not prove or disprove the ability of seepage to erode amphitheater-headed valleys in rock. The lack of processes-based observations of seepage erosion and the overlapping evidence for other processes makes it difficult to quantitatively assess the relative importance of seepage. Clearly more work is needed. On Earth, mechanistic studies are needed to identify the actual erosion mechanisms responsible for seepage erosion for a variety of lithologies and to determine their rate dependence, if any, with groundwater discharge. In addition, studies are needed to explore other processes that can produce amphitheaterheaded valleys in bedrock landscapes. On Mars, more information on lithology (or some measure of rock strength) and sediment size is needed to begin to decipher the role of seepage erosion in valley formation and to constrain the magnitude of the flows responsible for eroding the valleys.

[45] Acknowledgments. Funding was provided by NASA Astrobiology Institute grant to W.E. Dietrich. Thanks to the students of the Spring 2002 MIT class trip who made preliminary measurements of alcove morphology in Utah. We thank D. Pederson and an anonymous reviewer, whose comments improved this paper.

\section{References}

Aharonson, O., M. T. Zuber, D. H. Rothman, N. Schorghofer, and K. X Whipple (2002), Drainage basins and channel incision on Mars, Proc. Natl. Acad. Sci. U. S. A., 99(4), 1780-1783.

Baker, V. R. (1982), The Channels of Mars, Univ. of Tex. Press, Austin.

Baker, V. R. (1990), Spring sapping and valley network development, with case studies by R. C. Kochel, V. R. Baker, J. E. Laity, and A. D. Howard, in Groundwater Geomorphology; The Role of Subsurface Water in Earth- 
Surface Processes and Landforms, edited by C. G. Higgins and D. R. Coates, Spec. Pap. Geol. Soc. Am., 252, 235-265.

Baker, V. R., and J. B. Partridge (1986), Small Martian valleys: Pristine and degraded morphology, J. Geophys. Res., 91, 3561-3572.

Bakker, J. P., and J. W. N. Le Heux (1952), A remarkable new geomorphological law, Proc. K. Ned. Acad. Wet., Ser. B, 55, 399-410, 554-571.

Bandfield, J. L., V. E. Hamilton, and P. R. Christensen (2000), A global view of Martian surface compositions from MGS-TES, Science, 287(5458), 1626-1630.

Bennett, S. J., and J. Casali (2001), Effect of initial step height on headcut development in upland concentrated flows, Water Resour. Res., 37(5), 1475-1484.

Bennett, S. J., C. V. Alonso, S. N. Prasad, and M. J. M. Romkens (2000), Experiments on headcut growth and migration in concentrated flows typical of upland areas, Water Resour. Res., 36(7), 1911-1922.

Bishop, P., T. B. Hoey, J. D. Jansen, and I. L. Artza (2005), Knickpoint recession rate and catchment area: The case of uplifted rivers in eastern Scotland, Earth Surf. Processes Landforms, 30(6), 767-778.

Bollaert, E., and A. Schleiss (2003), Scour of rock due to the impact of plunging high velocity jets. Part I: A state-of-the-art review, J. Hydraul. Res., 41(5), 451-464.

Brown, M. E., A. H. Bouchez, and C. A. Griffith (2002), Direct detection of variable tropospheric clouds near Titan's south pole, Nature, 420(6917), $795-797$

Buffington, J. M., and D. R. Montgomery (1997), A systematic study of eight decades of incipient motion studies, with special reference to gravel-bedded rivers, Water Resour. Res., 33(8), 1993-2029.

Carr, M. H. (2002), Elevations of water-worn features on Mars: Implications for circulation of groundwater, J. Geophys. Res., 107(E12), 5131, doi:10.1029/2002JE001845.

Carr, M. H., and F. C. Chuang (1997), Martian drainage densities, J. Geophys. Res., 102, 9145-9152.

Carr, M. H., and G. D. Clow (1981), Martian channels and valleys-Their characteristics, distribution, and age, Icarus, 48, 91-117.

Clifford, S. M., and T. J. Parker (2001), The evolution of the Martian hydrosphere: Implications for the fate of a primordial ocean and the current state of the northern plains, Icarus, 154, 40-79.

Collins, G. C. (2005), Relative rates of fluvial bedrock incision on Titan and Earth, Geophys. Res. Lett., 32, L22202, doi:10.1029/2005GL024551.

Cooke, R. U., and W. R. Reeves (1976), Arroyos and Environmental Change in the American South-West, Clarendon, Oxford, U. K.

Craddock, R. A., and A. D. Howard (2002), The case for rainfall on a warm, wet early Mars, J. Geophys. Res., 107(E11), 5111, doi:10.1029/ 2001JE001505.

Craddock, R. A., R. P. Irwin, R. Williams, D. Swanson, A. D. Howard, C. Quantin, R. Kuzmin, and J. R. Zimbelman (2005), The geology of the Ka'u Desert, Hawaii as a Mars analog, Eos Trans. AGU, 86(52), Fall Meet. Suppl., Abstract H33C-1402.

Crosby, B. T., and K. X. Whipple (2006), Knickpoint initiation and distribution within fluvial networks in the Waipaoa River, North Island, New Zealand, Geomorphology, in press.

Cuda, V., and R. L. Ash (1984), Development of a uniaxial ice tensile specimen for low temperature testing, Cold Regions Sci. Technol., 9 , 47-52.

Dick, G. S., R. S. Anderson, and D. E. Sampson (1997), Controls on flash flood magnitude and hydrograph shape, Upper Blue Hills badlands, Utah, Geology, 25(1), 45-48.

Dietrich, W. E., and T. Dunne (1993), The channel head, in Channel Network Hydrology, edited by K. Beven and M. J. Kirkby, pp. 175-219, John Wiley, Hoboken, N. J.

Dietrich, W. E., D. Bellugi, L. Sklar, J. D. Stock, A. M. Heimsath, and J. J. Roering (2003), Geomorphic transport laws for predicting landscape form and dynamics, in Prediction in Geomorphology, Geophys. Monogr Ser., vol. 136, edited by P. Wilcock and R. Iverson, pp. 1-30, AGU, Washington, D. C

Dunne, T. (1980), Formation and controls of channel networks, Prog. Phys. Geogr., 4, 211-239.

Dunne, T. (1990), Hydrology, mechanics, and geomorphic implications of erosion by subsurface flow, in Groundwater Geomorphology: The Role of Subsurface Water in Earth-Surface Processes and Landforms, edited by C. G. Higgins and D. R. Coates, Spec. Pap. Geol. Soc. Am., 252, 1 28

Durham, W. B., H. C. Heard, and S. H. Kirby (1983), Experimental deformation of polycrystalline $\mathrm{H}_{2} \mathrm{O}$ ice at high pressure and low temperature: Preliminary results, Proc. Lunar Planet. Sci. Conf. 13th, Part 2, J. Geophys. Res., 88, suppl., B377-B392.

Faure, G. (1998), Principles and Applications of Geochemistry, 600 pp., Prentice-Hall, Upper Saddle River, N. J.

Gilbert, G. K. (1907), The rate of recession of Niagara Falls, U.S. Geol. Surv. Bull., 306, 1-31.
Goldspiel, J. M., and S. W. Squyres (1991), Ancient aqueous sedimentation on Mars, Icarus, 89, 392-410.

Goldspiel, J. M., and S. W. Squyres (2000), Groundwater sapping and valley formation on Mars, Icarus, 148, 176-192.

Goodman, R. E. (1989), Introduction to Rock Mechanics, 562 pp., John Wiley, Hoboken, N. J.

Grant, J. A. (2000), Valley formation in Margaritifer Sinus, Mars, by precipitation-recharged ground-water sapping, Geology, 28, 223-226.

Gregory, H. E. (1916), The Navajo country: A geography and hydrographic reconnaissance of parts of Arizona, New Mexico, and Utah, U.S. Geol. Surv. Water Supply Pap., W0380, 219 pp.

Griffith, C. A., J. L. Hall, and T. R. Geballe (2000), Detection of daily clouds on Titan, Science, 290, 509-513.

Griffith, C. A., et al. (2005), The evolution of Titan's mid-latitude clouds, Science, 310, 474-477.

Griffiths, P. G., R. H. Webb, and T. S. Melis (2004), Frequency and initiation of debris flows in Grand Canyon, Arizona, J. Geophys. Res., 109, F04002, doi:10.1029/2003JF000077.

Gulick, V. C. (1998), Magmatic intrusions and a hydrothermal origin for fluvial valleys on Mars, J. Geophys. Res., 103, 19,365-19,388.

Gulick, V. C. (2001), Origin of the valley networks on Mars: A hydrological perspective, Geomorphology, 37(3-4), 241-268.

Hamilton, V. E., and P. R. Christensen (2005), Evidence for extensive, olivine-rich bedrock on Mars, Geology, 33, 433-436.

Hanson, G. J., K. M. Robinson, and K. R. Cook (1997), Headcut migration analysis of a compacted soil, Trans. ASAE, 40(2), 355-361.

Hartmann, W. K., J. Anguita, M. A. de La Casa, D. C. Berman, and E. V. Ryan (2001), Martian cratering 7: The role of impact gardening, Icarus, 149, 37-53

Hayakawa, Y., and Y. Matsukura (2003), Recession rates of waterfalls in Boso Peninsula, Japan, and a predictive equation, Earth Surf. Processes Landforms, 28, 675-684

Heimsath, A. M., W. E. Dietrich, K. Nishiizumi, and R. C. Finkel (1997), The soil production function and landscape equilibrium, Nature, 388 , $358-361$.

Higgins, C. G. (1982), Drainage systems developed by sapping on Earth and Mars, Geology, 10, 147-152.

Higgins, C. G. (1984), Piping and sapping: Development of landforms by groundwater flow, in Groundwater as a Geomorphic Agent, edited by R. G. LaFleur, pp. 18-58, Allen and Unwin, St. Leonards, N. S. W. Australia.

Higgins, C., B. R. Hill, and A. K. Lehre (1990), Gully development, in Groundwater Geomorphology: The Role of Subsurface Water in EarthSurface Processes and Landforms, edited by C. G. Higgins and D. R. Coates, Spec. Pap. Geol. Soc. Am., 2521, 139-156.

Hinds, N. E. A. (1925), Amphitheatre valley heads, J. Geol., 33, 816818

Hoke, G. D., B. L. Isacks, T. E. Jordan, and J. S. Yu (2004), Groundwatersapping origin for the giant quebradas of northern Chile, Geology, 32, 605-608.

Holland, W. N., and G. Pickup (1976), Flume study of knickpoint development in stratified sediment, Geol. Soc. Am. Bull., 87(1), 76-82.

Hovius, N., C. P. Stark, M. A. Tutton, and L. D. Abbott (1998), Landslide-driven drainage network evolution in a pre-steady-state mountain belt: Finisterre Mountains, Papua New Guinea, Geology, 26, 1071 1074

Howard, A. D. (1988), Groundwater sapping on Earth and Mars, in Sapping Features of the Colorado Plateau, edited by A. D. Howard, R. C. Kochel, and H. R. Holt, NASA Spec. Publ., SP-491, 1-4.

Howard, A. D. (1994), Rockslopes, in Geomorphology of Desert Environments, edited by A. D. Abrahams and A. J. Parsons, pp. 123-172, CRC Press, Boca Raton, Fla.

Howard, A. D. (1995), Simulation modeling and statistical classification of escarpment planforms, Geomorphology, 12, 187-214.

Howard, A. D., and R. C. Kochel (1988), Introduction to cuesta landforms and sapping processes on the Colorado Plateau, in Sapping Features of the Colorado Plateau: A Comparative Planetary Geology Field Guide, edited by A. D. Howard, R. C. Kochel, and H. Holt, NASA Spec. Publ., SP-491, 6-56.

Howard, A. D., and C. F. McLane (1988), Erosion of cohesionless sediment by groundwater seepage, Water Resour. Res., 24(10), 1659-1674.

Howard, A. D., W. E. Dietrich, and M. A. Seidl (1994), Modelling fluvial erosion on regional and continental scales, J. Geophys. Res., 99, 13,97113,986 .

Hynek, B. M., and R. J. Phillips (2003), New data reveal mature, integrated drainage systems on Mars indicative of past precipitation, Geology, 31, 757-760.

Irwin, R. P., and A. D. Howard (2002), Drainage basin evolution in Noachian Terra Cimmeria, Mars, J. Geophys. Res., 107(E7), 5056 , doi:10.1029/2001JE001818. 
Irwin, R. P., R. A. Craddock, and A. D. Howard (2005), Interior channels in Martian valley networks: Discharge and runoff production, Geology, 33 , $489-492$.

Jaumann, R., and D. Reiss (2002), Nirgal Valles: Evidence for extensive sapping, Lunar Planet. Sci. [CD-ROM], XXXIII, Abstract 1579.

Jones, J. A. A. (1981), The Nature of Soil Piping; A Review, 301 pp., GeoBooks, Norwich, U. K.

Kochel, R. C., and V. R. Baker (1990), Groundwater sapping and the geomorphic development of large Hawaiian valleys, in Groundwater Geomorphology: The Role of Subsurface Water in Earth-Surface Processes and Landforms, edited by C. G. Higgins and D. R. Coates, Spec. Pap. Geol. Soc. Am., 252, 235-265.

Kochel, R. C., and J. F. Piper (1986), Morphology of large valleys on Hawaii-Evidence for groundwater sapping and comparisons with Martian valleys, J. Geophys. Res., Proc. Lunar Planet Sci. Conf. 17th, Part 1, 91, suppl., E175-E192.

Kochel, R. C., A. D. Howard, and C. F. McLane (1985), Channel networks developed by groundwater sapping in fine-grained sediments: Analogs to some Martian valleys, in Models in Geomorphology, edited by M. Woldenberg, pp. 313-341, Allen and Unwin, St. Leonards, N. S. W. Australia.

Laity, J. E. (1983), Diagenetic controls on groundwater sapping and valley formation, Colorado Plateau, revealed by optical and electron microscopy, Phys. Geogr., 4(2), 103-125.

Laity, J. E., and M. C. Malin (1985), Sapping processes and the development of theatre-headed valley networks on the Colorado Plateau, Geol. Soc. Am. Bull., 96, 203-217.

Lamb, M. P., W. E. Dietrich, and A. D. Howard (2004), Can springs cut valleys into bedrock?, Eos Trans. $A G U, 85(47)$, Fall Meet. Suppl., Abstract $\mathrm{H} 53 \mathrm{C}-1258$.

Lamb, M. P., A. D. Howard, W. E. Dietrich, and J. T. Perron (2005), Hawaiian analog for Martian amphitheatre-headed valleys, Eos Trans. $A G U, 86(52)$, Fall Meet. Suppl., Abstract H33C-1404.

Lobkovsky, A., B. Smith, D. Mohrig, A. Kudrolli, and D. Rothman (2005), Dynamical evolution of channels driven by subsurface flow, Eos Trans. $A G U, 86(52)$, Fall Meet. Suppl., Abstract H31A-1276.

Lorenz, R. D., and J. I. Lunine (1996), Erosion on Titan: Past and present, Icarus, 122, 79-91.

Luo, W. (2000), Quantifying groundwater-sapping landforms with a hypsometric technique, J. Geophys. Res., 105, 1685-1694.

Macdonald, G. A., A. T. Abbott, and F. L. Peterson (1983), Volcanoes in the Sea: The Geology of Hawaii, 517 pp., Univ. of Hawaii Press, Honolulu.

Malde, H. E. (1968), The catastrophic late Pleistocene Bonneville Flood in the Snake River Plain, Idaho, U.S. Geol. Surv. Prof. Pap., 596, 1-52.

Malin, M. C., and M. H. Carr (1999), Groundwater formation of Martian valleys, Nature, 397(6720), 589-591.

Malin, M. C., and K. S. Edgett (2000), Sedimentary rocks of early Mars, Science, 290, 1927-1937.

Malin, M. C., and K. S. Edgett (2003), Evidence for persistent flow and aqueous sedimentation on early Mars, Science, 302, 1931-1934.

Malin, M. C., et al. (1998), Early views of the Martian surface from the Mars orbiter camera of Mars Global Surveyor, Science, 279, 16811685 .

Mangold, N., C. Quantin, V. Ansan, C. Delacourt, and P. Allemand (2004), Evidence for precipitation on Mars from dendritic valleys in the Valles Marineris area, Science, 305, 78-81.

Mars Channel Working Group (1983), Channels and valleys on Mars, Geol. Soc. Am. Bull., 94, 1035-1054.

Mason, L. J., and D. T. Pederson (2004), Salt weathering of waterfall escarpments along the Niobrara River near Valentine, NE, Geol. Soc. Am. Abstr. Programs, 36(5), 231.

Mastronuzzi, G., and P. Sanso (2002), Pleistocene sea-level changes, sapping processes and development of valley networks in the Apulia region (southern Italy), Geomorphology, 46, 19-34.

Meinzer, O. E. (1927), Large springs in the United States, U.S. Geol. Surv. Water Supply Pap., 557, 42-51.

Meyer-Peter, E., and R. Müller (1948), Formulas for bed-load transport, in Proceedings, 2nd Congress, International Association of Hydraulic Re search, Stockholm, pp. 39-64, Int. Assoc. of Hydraul. Res., Madrid, Spain.

Moore, J. G., and D. A. Clague (1992), Volcano growth and evolution of the island of Hawaii, Geol. Soc. Am. Bull., 104(11), 1471-1484.

Moore, J. G., W. R. Normark, and R. T. Holcomb (1994), Giant Hawaiian landslides, Annu. Rev. Earth Planet. Sci., 22, 119-144.

Moore, J. M., and A. D. Howard (2005), Large alluvial fans on Mars, J. Geophys. Res., 110(E4), E04005, doi:10.1029/2004JE002352.

Moore, J. M., A. D. Howard, W. E. Dietrich, and P. M. Schenk (2003), Martian layered fluvial deposits: Implications for Noachian climate scenarios, Geophys. Res. Lett., 30(24), 2292, doi:10.1029/2003GL019002.
Nash, D. J. (1996), Groundwater sapping and valley development in the Hackness hills, north Yorkshire, England, Earth Surf. Processes Landforms, 21(9), 781-795.

O'Connor, J. E. (1993), Hydrology, Hydraulics and Geomorphology of the Bonneville Flood, Spec. Pap. Geol. Soc. Am., 274, 83 pp.

Onda, Y. (1994), Seepage erosion and its implication to the formation of amphitheater valley heads-A case-study at Obara, Japan, Earth Surf Processes Landforms, 19(7), 627-640.

Owoputi, L. O., and W. J. Stolte (2001), The role of seepage in erodibility, Hydrol. Processes, 15(1), 13-22.

Pederson, D. T. (2001), Stream piracy revisited: A groundwater sapping solution, GSA Today, 11(9), 4-10.

Perron, J. T., W. E. Dietrich, A. D. Howard, J. A. McKean, and J. R. Pettinga (2003), Ice-driven creep on Martian debris slopes, Geophys. Res. Lett., 30(14), 1747, doi:10.1029/2003GL017603.

Perron, J. T., M. P. Lamb, C. D. Koven, I. Y. Fung, E. Yager, and M. Adamkovics (2006), Valley formation and methane precipitation rates on Titan, J. Geophys. Res., doi:10.1029/2005JE002602, in press.

Pieri, D. (1976), Distribution of small channels on Martian surface, Icarus, $27,25-50$

Pieri, D. C. (1980), Martian valleys: Morphology, distribution, age, and origin, Science, 210, 895-897.

Pillans, B. (1985), Drainage initiation by subsurface flow in South Taranaki, New Zealand, Geology, 13, 262-265.

Porco, C. C., et al. (2005), Imaging of Titan from the Cassini spacecraft, Nature, 434(7030), 159-168.

Rest, R. J., R. G. Scurlock, and M. F. Wu (1990), The solubilities of nitrous oxide, carbon dioxide, aliphatic ethers and alcohols, and water in cryogenic liquids, Chem. Eng. J., 43, 25-31.

Robinson, K. M., and G. J. Hanson (1996), Gully headcut advance, Trans. ASAE, 39(1), 33-38.

Rosenblum, N. A., and R. S. Anderson (1994), Hillslope and channel evolution in a marine terraced landscape, Santa Cruz, California, J. Geophys. Res., 99, 14,013-14,029.

Russel, I. C. (1902), Geology and water resources of the Snake River Plains of Idaho, U.S. Geol. Surv. Bull., 199, 1-192.

Schorghofer, N., B. Jensen, A. Kudrolli, and D. H. Rothman (2004), Spontaneous channelization in permeable ground: theory, experiment, and observation, J. Fluid Mech., 503, 357-374.

Schubert, G. S., T. Spohn, and R. T. Reynolds (1986), Thermal histories, compositions and internal structures of the moons of the solar system, in Satellites, edited by J. A. Burns and M. S. Matthews, pp. 224-292, Univ. of Ariz. Press, Tucson.

Schumm, S. A., and L. Phillips (1986), Composite channels of the Canterbury Plain, New Zealand: A Martian analog?, Geology, 14, 326-329.

Schumm, S. A., K. F. Boyd, C. G. Wolff, and W. J. Spitz (1995), A groundwater sapping landscape in the Florida panhandle, Geomorphology, 12(4), 281-297.

Scott, D. H., and K. L. Tanaka (1986), Geologic map of the western equatorial region of Mars, U.S. Geol. Surv. Misc. Invest. Map, I-1802-A.

Seidl, M. A., W. E. Dietrich, and J. W. Kirchner (1994), Longitudina profile development into bedrock: An analysis of Hawaiian channels, J. Geol., 102, 457-474.

Seidl, M. A., J. K. Weissel, and L. F. Pratson (1996), The kinematics and pattern of escarpment retreat across the rifted continental margin of SE Australia, Basin Res., 8(3), 301-316.

Sharp, R. P., and M. C. Malin (1975), Channels on Mars, Geol. Soc. Am Bull, 86(5), 593-609.

Sklar, L. S., and W. E. Dietrich (2001), Sediment and rock strength controls on river incision into bedrock, Geology, 29, 1087-1090.

Sklar, L. S., and W. E. Dietrich (2004), A mechanistic model for river incision into bedrock by saltating bed load, Water Resour. Res., 40, W06301, doi:10.1029/2003WR002496.

Smith, J. R., K. Satake, J. K. Morgan, and P. W. Lipman (2002), Submarine landslides and volcanic features on Kohala and Mauna Kea volcanoes and the Hana Ridge, Hawaii, in Hawaiian Volcanoes: Deep Underwater Perspectives, Geophys. Monogr. Ser, vol. 128, edited by E. Takahashi et al., pp. 11-28, AGU, Washington, D. C

Squyres, S. W. (1989), Urey Prize lecture: Water on Mars, Icarus, 79, 229288

Squyres, S. W., and J. F. Kasting (1994), Early Mars: How warm and how wet, Science, 265, 744-749.

Stark, C. P. (1994), Cluster growth modeling of plateau erosion, J. Geophys Res., 99, 13,957-13,969.

Stearns, H. T. (1936), Origin of the large springs and their alcoves along the Snake River in southern Idaho, J. Geol., 44, 429-450.

Stearns, H. T. (1985), Geology of the State of Hawaii, 266 pp., Pac. Books, Palo Alto, Calif.

Stearns, H. T., and G. A. Macdonald (1946), Geology and ground-water resources of the island of Hawaii, Hawaii Div. Hydrogr. Bull., 9, 363 pp. 
Stearns, H. T., and K. N. Vaksvik (1935), Geology and ground-water resources of the island of Oahu, Hawaii, Hawaii Div. Hydrogr. Bull., 1, 479 pp.

Tanaka, K. L. (1986), The stratigraphy of Mars, Proc. Lunar Planet. Sci. Conf. 16th, Part 1, J. Geophys. Res., 91, suppl., E139-E158.

Tanaka, K. L., J. M. Dohm, J. H. Lias, and T. M. Hare (1998), Erosiona valleys in the Thaumasia region of Mars: Hydrothermal and seismic origins, J. Geophys. Res., 103, 31,407-31,420.

Tauxe, L., C. Luskin, P. Selkin, P. Gans, and A. Calvert (2004), Paleomagnetic results from the Snake River Plain: Contribution to the time-averaged field global database, Geochem. Geophys. Geosyst., 5, Q08H13, doi:10.1029/2003GC000661.

Tomasko, M. G., et al. (2005), Rain, wind and haze during the Huygens probe's decent to Titan's surface, Nature, 438, 765-778, doi:10.1038/ nature 04126.

Uchupi, E., and R. N. Oldale (1994), Spring sapping origin of the enigmatic relict valleys of Cape Cod and Martha's Vineyard and Nantucket Islands, Massachusetts, Geomorphology, 9(2), 83-95.

Webb, R. H., P. T. Pringle, and G. R. Rink (1989), Debris flows from the tributaries of the Colorado River, Grand Canyon National Park, Arizona U.S. Geol. Surv. Prof. Pap., 1492, 1-39.

Weissel, J. K., and M. A. Seidl (1997), Influence of rock strength properties on escarpment retreat across passive continental margins, Geology, 25, $631-634$

Wentworth, C. K. (1928), Principles of stream erosion in Hawaii, J. Geol., $36,385-410$.

Whipple, K. X. (2004), Bedrock rivers and the geomorphology of active orogens, Annu. Rev. Earth Planet. Sci., 32, 151-185.
Whipple, K. X., G. S. Hancock, and R. S. Anderson (2000), River incision into bedrock: Mechanics and relative efficacy of plucking, abrasion, and cavitation, Geol. Soc. Am. Bull., 112(3), 490-503.

Whiting, P. J., and J. Stamn (1995), The hydrology of spring-dominated channels, Geomorphology, 12, 233-240.

Willgoose, G., R. L. Bras, and I. Rodriguez-Iturbe (1991), A coupled channel network growth and hillslope evolution model: 1. Theory, Water Resour. Res., 27(7), 1671-1684.

Williams, R. M. E., and R. J. Phillips (2001), Morphometric measurements of Martian valley networks from Mars Orbiter Laser Altimeter (MOLA) data, J. Geophys. Res., 106, 23,737-23,751.

Wong, M. (2006), Model for erosion, transport and deposition of tracer stones in gravel-bed streams, Ph.D. thesis, Univ. of Minn. Twin Cities, Minneapolis.

Yoshida, M., and H. Ikeda (1999), The origin of the Ryumon Falls in Karasuyama Town, Tochigi Prefecture, Bull. Environ. Res. Cent. Univ. Tsukuba, 24, 73-79.

Young, R. (1985), Waterfalls: Form and process, Z. Geomorphol. Suppl., $55,81-95$.

W. E. Dietrich, M. P. Lamb, and J. T. Perron, Department of Earth and Planetary Science, 307 McCone Hall, University of California, Berkeley, CA 94720, USA. (mpl@berkeley.edu)

A. D. Howard, Department of Environmental Sciences, P.O. Box 400123 University of Virginia, Charlottesville, VA 22903, USA.

J. Johnson and K. X. Whipple, Department of Earth Atmospheric and Planetary Science, MIT, Cambridge, MA 02139, USA 